\title{
Identification of Geoheritage Elements in a Cultural Landscape: a Case Study from Tokaj Mts, Hungary
}

\author{
János Szepesi ${ }^{1,2}$ (1) Z Zsuzsanna Ésik ${ }^{2,3} \cdot$ Ildikó Soós $^{1,7} \cdot$ Boglárka Németh $^{4} \cdot$ László Sütö $^{5} \cdot$ Tibor József Novák $^{6}$. \\ Szabolcs Harangi ${ }^{1,7} \cdot$ Réka Lukács $^{1}$
}

Received: 20 February 2020 / Accepted: 21 October 2020

(C) The European Association for Conservation of the Geological Heritage 2020

\begin{abstract}
Cultural landscapes were developed as a result of continuous interaction between nature and human culture. During their evolution, the geodiversity was also considerably influenced by human activities. Recently, geoheritage studies have become more sensitive towards man-made cultural landmarks. In this paper, we explore a methodology to compile a regional inventory for a historic mountainous cultural landscape with remarkable geological, volcanological, and mining heritage in Tokaj Mts, (NE Hungary). The databases of the natural and cultural heritage contribute to the extension of regional inventories with a large number of geodiversity-related records. The specific selection procedure with a combination of GIS and fieldwork assessment resulted in the final list of potential sites. The applied three stage classification forms a basis for territorial analysis. The selected 60 geosites of $700 \mathrm{~km}^{2}$ represents well the geological history of the study area, while another 160 geodiversity and geocultural sites emphasize further enhancement of natural and cultural diversity. The functional classification referring to the physical nature of the sites was useful to define specific conservation management priorities. The thematic grouping of the sites defined new interpretation possibilities for geotourism and geoeducation taking into account volcanological, geomorphological, and mining heritage values.
\end{abstract}

Keywords Cultural landscape $\cdot$ Volcanic geoheritage $\cdot$ Geosite $\cdot$ Geocultural $\cdot$ Geotourism

Supplementary Information The online version contains supplementary material available at https://oi.org/10.1007/s12371-02000516-w.

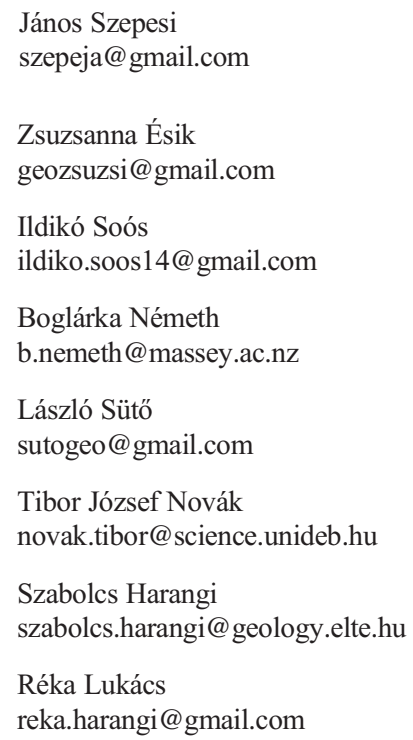

1 MTA-ELTE Volcanology Research Group, Pázmány Péter Sétány 1/c, Budapest H-1117, Hungary

2 Isotope Climatology and Environmental Research Centre (ICER), Institute for Nuclear Research, Debrecen, Hungary

3 Department of Mineralogy and Geology, University of Debrecen, Egyetem Tér 1, Debrecen H-4010, Hungary

4 School of Agriculture and Environment, Massey University, Turitea Campus, Palmerston North, New Zealand

5 Institute of Geography and Environmental Sciences, Eszterházy Károly University, 6-8 Leányka u, Eger, Hungary

$6 \quad$ University of Debrecen Department of Landscape Protection and Environmental Geography, Egyetem Tér 1, Debrecen H-4010, Hungary

7 Department of Petrology and Geochemistry, Eötvös University, Pázmány Péter Sétány 1/c, Budapest H-1117, Hungary 


\section{Introduction}

The concept of geodiversity, involving abiotic elements of the environment in nature conservation emerged as a scientific topic in the last decade of the twentieth century (Sharples 1993, 2002; Gray 2004, 2008). The first strictly geological meaning expanded, and today geodiversity is commonly regarded as the natural range of geological (rocks, minerals, fossils, basic profiles), geomorphological (landforms, processes), hydrological, and soil features (Gray 2004). Geoheritage refers to in situ occurrences of geodiversity features (Brilha 2016). Human activities have a considerably effect on geodiversity. The so-called cultural landscapes were developed as a result of continuous interaction between nature and humans and reflects on the cultures which created them (International Council on Monuments and Sites 2008; Mitchell et al. 2009; Li et al. 2019). Cultural landscapes evolved over time spanning thousands of years of history. Their heritage comprises tangible (movable and immovable) and intangible elements (Gordon 2018a). Immovable tangible components include anthropogenic landforms, historic, industrial, and cultural buildings providing important resources for geoconservation. Although, movable features (fossils, sculptures) are also important. Based on this, heritage is a complex concept (Coratza and Hobléa 2018) depending on the society that attributes importance for conservation and transmission to future generations (Reynard and Giusti 2018).

Systematic site inventories are based on scientific, aesthetic, protection, and touristic relevance of geoheritage elements (Fuertes-Gutierrez and Fernandez-Martinez 2012; Rolfo et al. 2015; Brilha 2016; Poiraud et al. 2016; Zangmo et al. 2020). Despite the fact that these studies deal with geosite inventory and assessment, too little attention has been paid to the evaluation of cultural landscape diversity as yet (Coratza et al. 2016; Gordon 2018a, b). The recent review of inventories (Brilha 2016) proposed a new methodological approach for defining geosites as those that have pure scientific value, and those geodiversity sites that exhibit educational or geotourism or cultural identity values. This approach however leaves a significant amount of geodiversity-related objects without classification. Cultural geomorphology studies (Carreras and Druguet 1999; Reynard and Giusti 2018) identified material and immaterial elements of cultural landscapes and defined geocultural sites where the geological features interact with cultural elements. Although these provide a good methodological basis for processing special cultural landscapes, few detailed case studies are available in the literature (e.g., Migoń and Latocha 2013; Szepesi et al. 2017; Kubalikova 2019)

Our study was conducted in the northern part of Tokaj Mountains (NTM, Fig. 1) located along the HungarianSlovakian border in Central Europe. The mountain range is a special mountainous cultural landscape characterized by its historical, mining-industrial, and agricultural (forestry) traditions. The study area was subject of a former geological and a recent volcanological mapping and a complete settlement-based database of "unique landscape value" cadaster (MSZ 20381:2009; for explanation, see the supplementary material) was also provided for the area. This cadaster is widely used in Hungarian landscape conservation practices because of its special relevance to the natural and anthropogenic values of cultural landscapes. Here, we demonstrate that the above-mentioned field surveys are appropriate for the compilation of a comprehensive preinventory and the establishment of a sound geosite selection procedure. Finally, we propose a detailed classification of cultural landscape geodiversity using a methodological, functional and thematic approach. The schemes are suitable for defining geoconservation strategies and spatial planning policies in geoconservation, geotourism, and geoeducation.

\section{Cultural Landscape of the Tokaj Mountains}

Tokaj Mountains (TM) is located in the northeastern part of Hungary as the last member of a medium height mountain zone along the Hungarian-Slovakian border, covering approximately $1100 \mathrm{~km}^{2}$. The southern part of TM is composed of the Tokaj Wine Region Historic Cultural Landscape (Fig. 1), a gentle sloping hilly, agricultural area which was declared as a UNESCO World Heritage Site in 2002 (Szepesi et al. 2017). In contrast, the northern part is a mountainous area with forestry and historical industry (Fig. 2). The whole mountain is mainly built up by Miocene volcanic rocks. Pleistocene river sediments deposited only along the valleys bordering the mountains (Fig. 1) at the east (Bodrog) and west (Hernád). The study area encompasses only the northern part of the Tokaj Mountains (NTM), stretching north to the Slovakian border including 44 settlements with an area of $700 \mathrm{~km}^{2}$. From nature conservation point of view only one third of the study area (Fig. 1) overlaps the Zemplén Landscape Protection Area (Table 1) managed by the Aggtelek National Park Directorate. Furthermore, two additional nature conservation areas, a natural monument and a geological key section, were declared by the nature conservation legislation (Table 1).

Relief conditions caused a very unbalanced distribution of both the economic and demographic development. The settlements concentrated along the rivers and mountain valleys facilitating main transportation routes from mediaeval ages. There are only three cross mountain corridors with extended uninhabited areas in central NTM. Natural resources (Fig. 2) attracted mining activities, the glasswork industry, and forestry. The proximity of the Hungarian-Slovakian border indicates very strong political changes during the twentieth century which caused identical demographic and socio-cultural shifts. The whole NTM is a rural environment with two small 


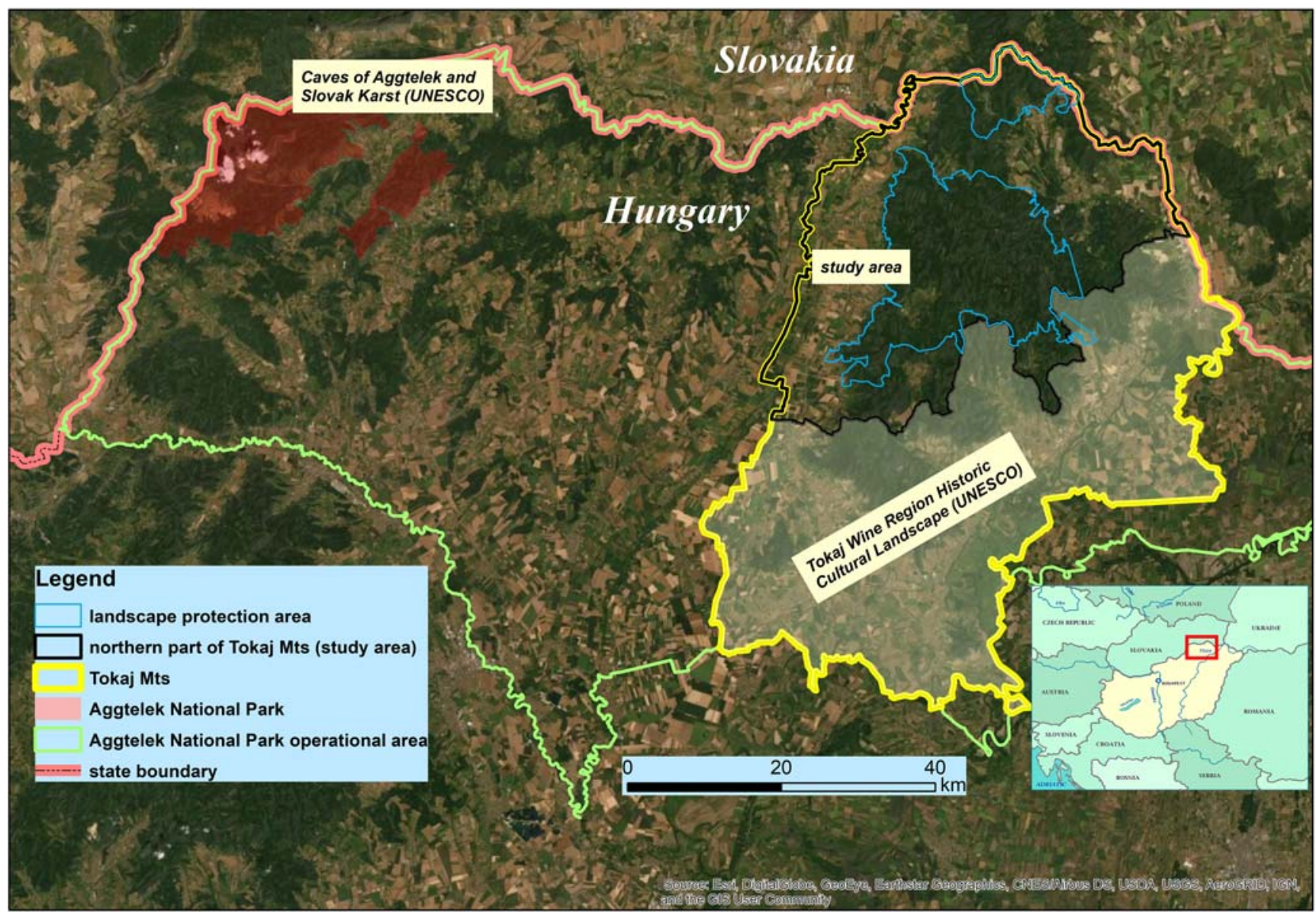

Fig. 1 The geographical location of the study area

towns where economy is based on agriculture and forestry. The population decline was continuous during the decades of socialism, and the size of local communities dropped by more than $50 \%$ in some villages. The largest settlements have just received urban status recently, but their population hardly exceeds 2000 inhabitants. In recent years, HungarianSlovakian cross-border development projects established regional progress regarding infrastructure, community services, and tourism.

\section{Geodiversity of the Cultural Landscape}

Despite the dominance of volcanic rocks, lithological conditions are highly variable (Fig. 2c). Repeated andesitic to rhyolitic volcanic eruptions took place from ca. 15 to $10 \mathrm{Ma}$ (Pécskay et al. 2006; Kiss et al. 2011), in a transitional shallow marine to subaerial environment (Kováč et al. 2007; Piller et al. 2007). The volcanic landforms (Zelenka et al. 2012; Szepesi et al. 2018b, 2019) consist of caldera systems, rhyolitic lava dome fields, andesitic-dacitic composite volcanoes, and eroded outcropping intrusions (e.g., laccolith). Glassy volcanic rocks (perlites) are also associated with the Miocene lava domes with highest volumes in the Carpathian
Basin (Zelenka et al. 2012; Szepesi et al. 2019). The central and northern parts of the NTM with the dominance of hard volcanic rocks are characterized by variable heights and slopes (Fig. 2a, d). The highest peak of the mountains is located at the north along the border (Nagy Milic, $896 \mathrm{~m}$ ). During the cold phases of the Pleistocene, the geomorphology of the mountains changed significantly, typical periglacial forms developed with frost-riven cliffs, block streams, and cryoplanation terraces (Pinczés 1998). Denudation was more intense on the erodible rhyolitic volcaniclastics with the formation of an intramontane basin (Hegyköz) and pediment surfaces (200-400 m a.s.1.). These pediments were sometimes dissected by deep gullies (10-25 m) during the young Pleistocene-Holocene uplift. Along the rivers, the elevation is less than $200 \mathrm{~m}$ a.s.l. (Fig. 2a), where the fluvial sedimentation coupled with the development of river terraces, oxbow lakes.

The utilization of geodiversity has a long tradition in the NTM dating back to the obsidian and quartzite tool production of Paleo and Neolithic cultures (Bíró 1984, 2002; Frisnyák 2009). Most of the minerals have been quarried since the Middle Ages as reflected in the heraldry of a number of settlements (Fig. 3). The center of gold and silver mining was 

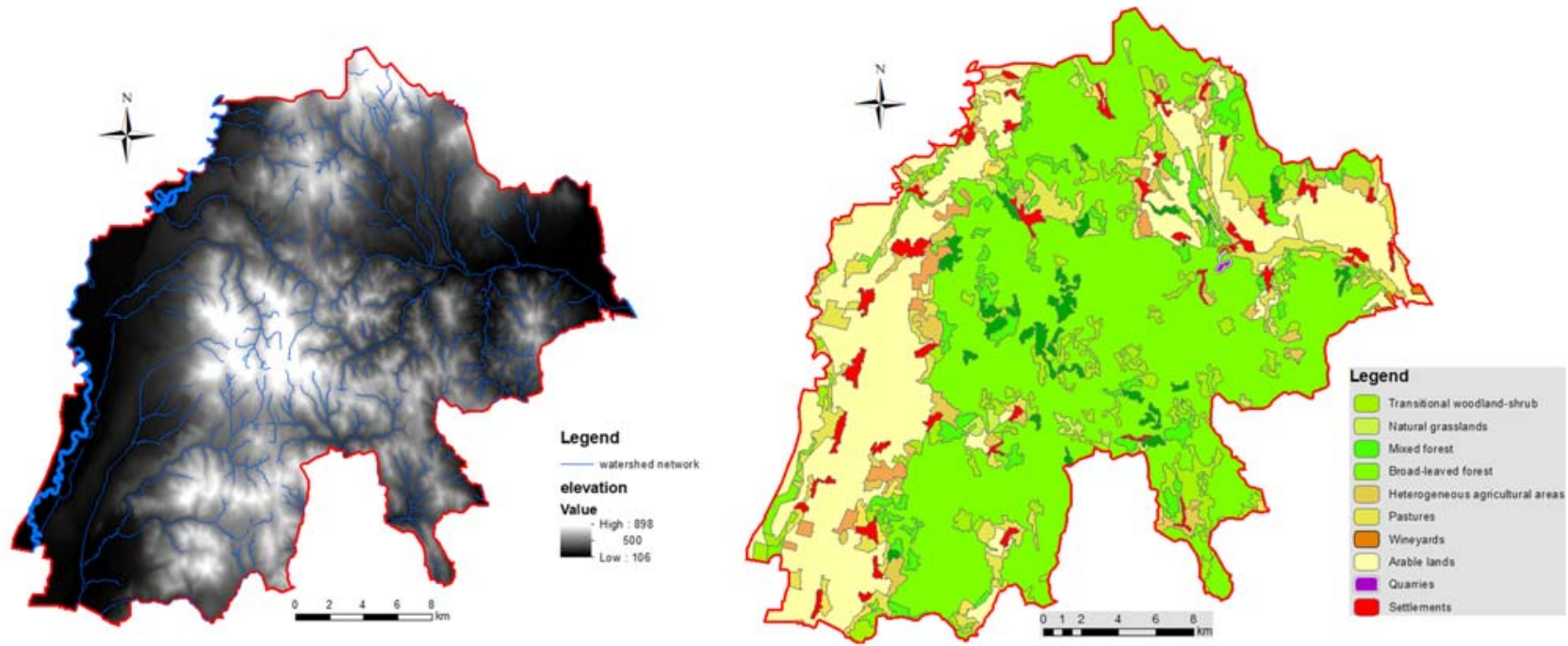

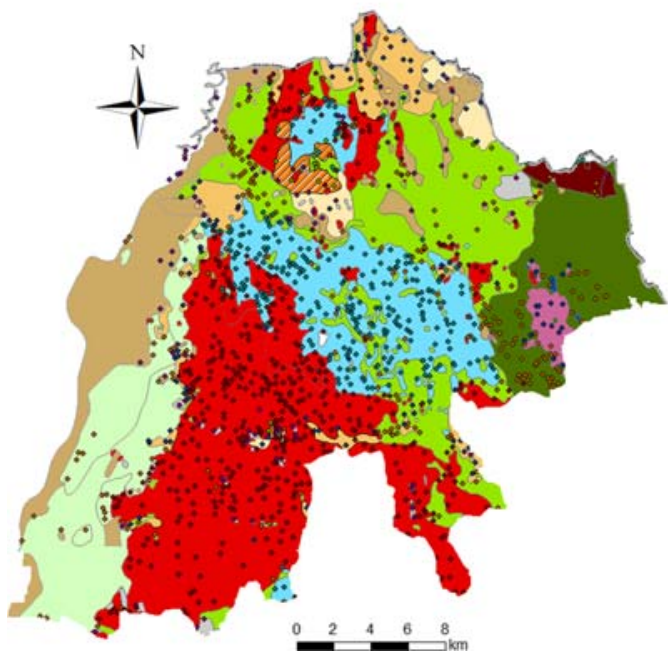

Fig. 2 Thematic cartography of study area. a Relief map (SRTM global DEM https://ta.cr.usgs.gov/SRTM1Arc) and watercourses (b land cover (CORINE Land Cover 2006), c geological map and outcrops (based on 1:

Telkibánya (Fig. 3a). The initial works on the surface (twelfth-thirteenth centuries) with open-pit fields were replaced later by underground mines. Clay minerals were first
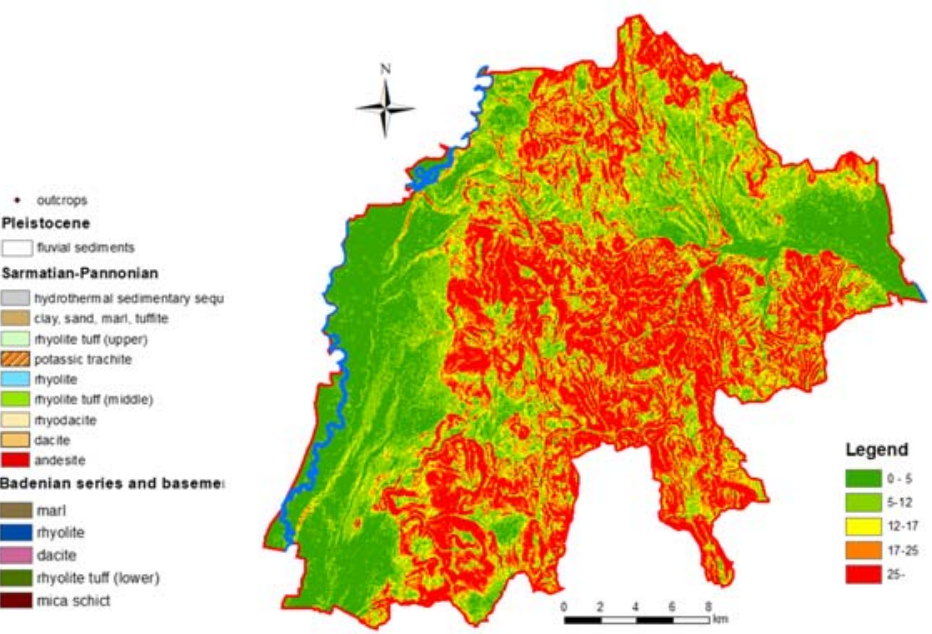

25,000 map sheets; Erhardt and Pentelényi 1966; Gyarmati 1963, 1966, 1972; Gyarmati and Pentelényi 1973; Ilkey-Perlaki 1967, 1971, 1977; Pentelényi 1970, 1971, 1972), d and slope map (based on SRTM DEM )

exploited from Telkibánya with the establishment of a porcelain manufactory. As stocks were running out, the factory was moved later to Hollóháza, while new mines were opened in

Table 1 Hungarian nature conservation acts and decrees with special targets in the study area. For detailed information of the geoconservation acts, see the supplementary material

\begin{tabular}{lll}
\hline Act No. & Territorial scope & Target in study area \\
\hline $\begin{array}{lll}\text { Act No. 53. of 1996 } \\
\begin{array}{l}\text { National Nature Conservation } \\
\text { Act }\end{array}\end{array}$ & Protected natural areas & $\begin{array}{c}\text { Zemplén Landscape Protection Area (Established in 1984, } \\
\text { 27,783 ha) } \\
\text { Abaújkér-Aranyos valley (2007) }\end{array}$ \\
& Nature conservation areas & Füzérradvány Castle Park (2007) \\
& Natural monument & Devil's Rock, Abaújkér \\
& ex lege protection & all wells, caves, motte \\
Decree No. 13 of 1991 & $\begin{array}{l}\text { Site protection basic geological profiles) } \\
\text { Decree No. 15 of 2015 }\end{array}$ & Site protection (basic geological sections, outcrops, \\
& landforms) & Ongoing field survey (30 sites) before declared protection \\
\end{tabular}


Fig. 3 Geodiversity elements in settlements heraldry. a

Telkibánya: uniform miners on both side of the castle with hammer and pick. b Pálháza: a triple green pile at the lower side of the shield with miner's symbol (hammer and pick). c Hollóháza: ceramics on the upper right side of the shield. d Vágáshuta: traditional glass industry on the lower side of the shield. Golden flames of fire flowing out of three openings, two workers in green cloth blowing blue glass jug, and a blue jug glass jug in the foreground

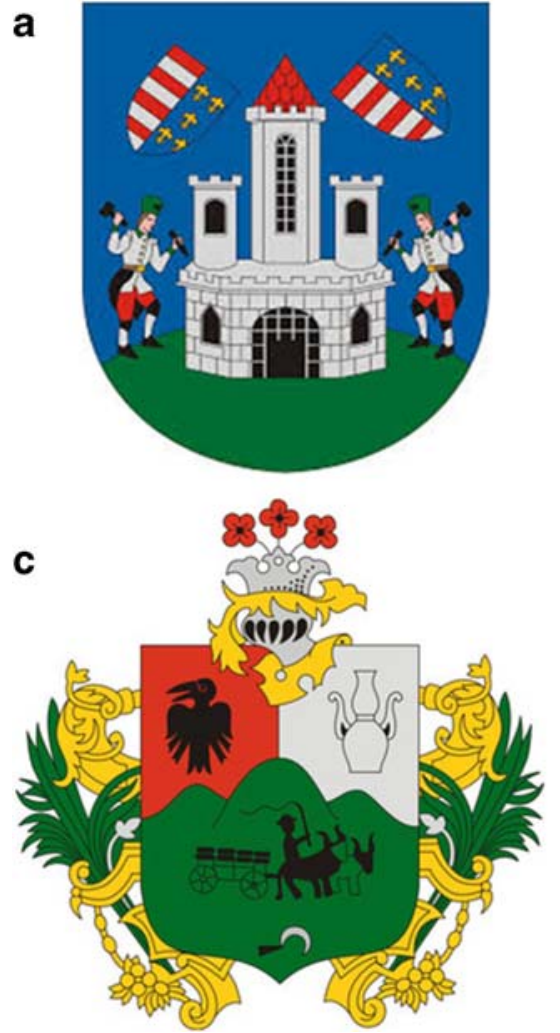

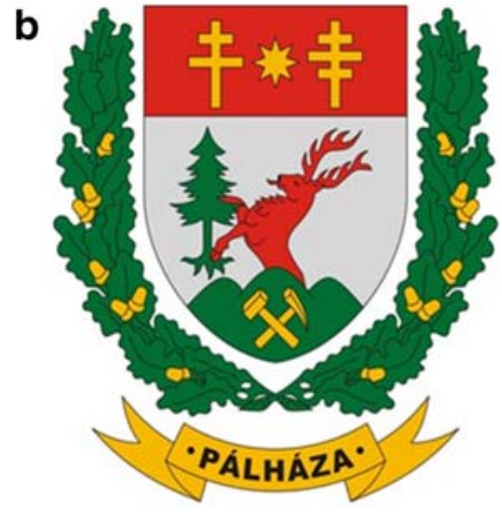

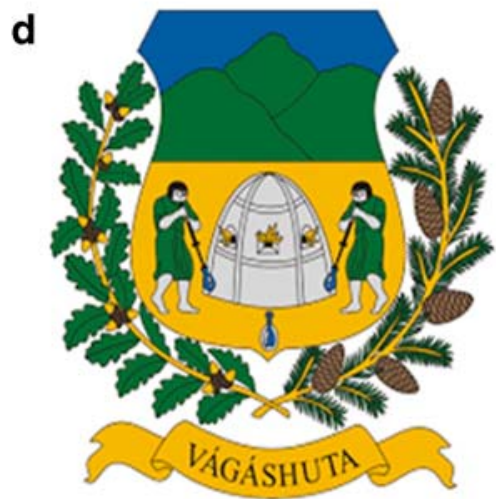

the Füzérradvány area. The manufactory has grown to become one of the most famous porcelain factories in Europe as highlighted by a porcelain vase in the crest of Hollóháza (Fig. 3c). Traditional glasswork was started in the sixteenth century and the last factory was closed in 1921. The designation "Huta=glasswork" is still preserved in the name of 6 settlements and refers to the once famous industry. The crest of Vágáshuta displays the manufacture and the famous blue jugs (Fig. 3d). The largest perlite quarry for modern building industry is still operating (Pálháza, Fig. 3b).

\section{Previous Works and Database}

\section{Geological and Volcanological Mapping}

Studying the TM has one of the longest history in the Carpathian Basin starting from the eighteenth century during the plutonist-neptunist debate (Fichtel 1791; Esmark 1798; Richthofen 1861). The last comprehensive geological mapping was carried out from the 1960s at a scale of 1:25,000, compiling observation registers and general lithological thematic maps. The study area is covered by 12 map sheets (Erhardt and Pentelényi 1966; Gyarmati 1963, 1966, 1972; Gyarmati and Pentelényi 1973; Ilkey-Perlaki 1967, 1971, 1977; Pentelényi 1970, 1971, 1972). The surface rock occurrences classified into three categories: outcrop, dense, and rare debris. The types of hydrothermal alterations, tectonic lines, and dips were also indicated. The symbols of quarries, medieval adits, and paleontological sites with major boreholes gives additional information. Each map sheet has a detailed explanatory note with a special raw material chapter. Since the completion of the last geological mapping, there have been many new achievements in the descriptive and interpretive methodology of the international volcanology research. MTA-ELTE Volcanology Research Group started a detailed mapping work in 2013 for the complete volcanological reconstruction of the mountains. During the concomitant fieldwork, the outcrops attained from the available geological maps were identified and logged using lithology/lithofacies as a basic mapping unit. Horizontal and vertical correlations allowed for the recognition of Miocene volcanic centers and the establishment of a new stratigraphic and evolutional framework for TM (e.g., Szepesi et al. 2018b, 2019).

\section{Unique Landscape Value Cadaster}

Rapid changes in the last century in environmental diversity triggered a new perception of cultural and natural landscapes. The Hungarian nature conservation legislation inducted a new term, called "unique landscape values" in the 1996 LIII Nature Conservation Act (see the supplementary material). As interpreted, unique landscape values are characteristic landscape elements from natural origin or created by human activities and 
represent natural, historical, cultural, scientific, or aesthetic importance to the local community. The survey shall be conducted in the entire administrative area of a settlement for its implementation into a municipality-based cadaster. Data management and storage were carried out in Nature Conservation Information System special unique landscape values module with up to 20,000 records collected in 2012. The Nature conservation, Unique landscape values Hungarian Standard (MSZ 20381:2009) provides guidelines to carry out fieldwork surveys and database management (Tóth et al. 2012). Although the national processing level is only $26 \%$, the study area reached $100 \%$. The major survey categories are the cultural and natural heritage and landscape values (Table 2).

\section{Public Mineral Collector Database}

Rock, mineral, and fossil-collecting activities became more and more popular in Hungary in the 1970 and 1980s. The first topography based comprehensive publication of Hungarian mineral species was published soon (Szakáll and Gatter 1993) for public interest. Thematic websites were becoming more widespread during the 2000s. The continuous increase in the number of mineral collectors established a site-based compilation in 2007 (www.geomania.hu). The website interface (after registration) allows to upload new site photos and upgrade information about current conditions. The national database contains 685 site entries with 17,654 mineral and 3163 site photos. The hydrothermal deposits (natural outcrops, quarries) of TM are very frequented and visited by the collectors. One sixth of the entire database (112 sites) were published from TM (including the Tokaj Wine Region Historic Cultural Landscape Szepesi et al. 2017); out of which 59 are related to the study area.

\section{Methods and Fieldwork}

The methodology was divided into four different parts (Fig. 4) following the regional geosite identification priorities
(Regolini-Bissig and Reynard 2010; Brilha 2016; Poiraud et al. 2016; Faccini et al. 2018). After the preliminary field surveys and preinventory compilation, the main purposes were (1) to find a proper selection procedure, (2) to emphasize the geodiversity of the NTM, (3) to establish a basic classification scheme, and (4) to provide a development strategy for the future.

\section{GIS Database Management}

The development of a preinventory was based on the careful processing of mapping resources including the whole material from the previous chapter. All site-based data were recorded in an ArcGIS geodatabase. The above-described geological framework can be defined as the main subject of the preinventory (Fig. 2c). The database included the outcrops of the geological maps and the recent volcanological mapping, as well as the sites of the public mineral collector database finally containing more than 1000 records. The national unique landscape cadaster was used to select additional sites for the preinventory (details in the supplementary material) in order to emphasize the community use of geomaterials. Considerable geodiversity objectives were attached to almost every cadaster class (Table 2 ) resulting in a database excluding only the biodiversity category. After completing data integration, the general preinventory density (object $/ \mathrm{km}^{2}$ ) was calculated in GIS environment. This analysis was also performed after the selection procedure (site/ $\mathrm{km}^{2}$ ) identifying regional hotspots (settlements and areas) with high geodiversity potential.

\section{Selection and Classification}

The major aim of the selection procedure was to identify potential sites from the preinventory (Fuertes-Gutierrez and Fernandez-Martinez 2012; de Lima et al. 2010; Poiraud et al. 2016). Selection was based on the representativeness, integrity rarity, and scientific knowledge about the sites (Brilha 2016). The application of the above criteria excluded

Table 2 Types of unique landscape values and proportion in the national cadaster (percentages from Tóth et al. 2012)

\begin{tabular}{ll}
\hline Major categories & Unique landscape values \\
\hline Cultural heritage & Settlement related \\
& Transportation \\
& Industrial \\
& Other industry values \\
Natural values & Geodiversity values \\
& Biodiversity values \\
Landscape values & Viewpoint with unique or characteristic view \\
& Linear lookout is unique or distinctive visual image \\
& Non-classified \\
\hline
\end{tabular}


Fig. 4 Flowchart of the methodological approach and analysis process

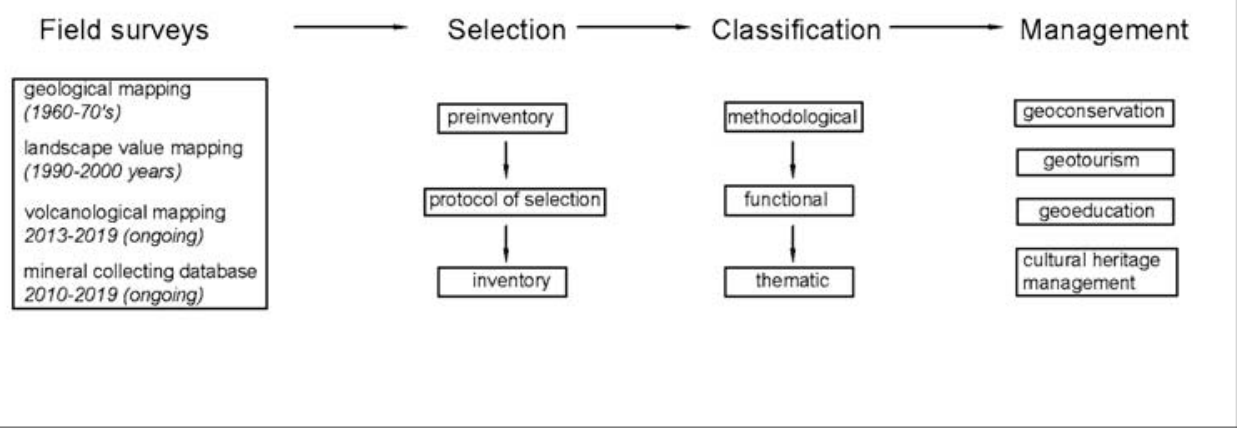

the potential geosites for further classification. The sites without particular relevance of scientific value were further analyzed using educational and touristic interests (Table 2; Brilha 2016) and defined as geodiversity sites (or local sites of importance, Browne 2012). The application of additional criteria set from the Scottish geoconservation methodology (Table 3; Browne 2012) emphasized the cultural and community significance, potential archeology, and built heritage link and defined additional sites by contributing to the cultural landscapes. The special attributes of protection status (Telkibánya feeder dyke, Fig. 8e; Vizsoly quarry, Fig. 8f) and damage threats (mineral collection) gave particular importance to some objects. Finishing the selection, the result was converted to a definitive list of potential sites of the natural geodiversity and cultural landscape diversity. Classification is common concept in evaluating geological heritage (FuertesGutiérrez and Fernández-Martínez 2010; Poiraud et al. 2016; Mauerhofer and Reynard 2018). A three-level method was applied regarding methodological, functional, and thematic issues that are widely implementable especially into regional database compilation, local site management, geotourism, geoeducation, and geoconservation actions (e.g., Zangmo et al. 2017).

\section{Fieldwork and Assessment}

The detailed fieldwork and assessment of the selected geoand cultural diversity sites included several criteria as published in (geo)site assessment methods (Reynard et al. 2007; Vujičić et al. 2011; Zouros 2005). Based on, Brilha (2016), the fieldwork focused on the following parameters that define site management priorities: geoconservation purposes, degradation risk, and further educational, touristic relevance. The applied indicators were representativeness, key locality, the scientific knowledge, integrity, geological diversity, rarity, use limitations, accessibility current observation conditions, vulnerability, educational potential, safety, and association with other values. Considering functional values, the directly site-related parameters as additional values (natural and anthropogenic), tourism infrastructure and interpretative panels were logged. The fieldwork was partly overlapped by special geoconservation-based field survey coordinated by the Aggtelek National Park from 2015. The individual site mapping identified and described 40 vulnerable objects in the study area. Furthermore, an extensive field campaign was carried out at a scale of 1:1000 in 2018 (including the authors) studying the Telkibánya Medieval Gold-Silver Mining Area

Table 3 Selecting criteria of geosites, geodiversity sites, and qualitative assessment of educational and touristic value

\begin{tabular}{|c|c|c|c|c|}
\hline $\begin{array}{l}\text { Main criteria for } \\
\text { selecting geosites } \\
\text { (Brilha 2016) }\end{array}$ & $\begin{array}{l}\text { Main criteria for selecting } \\
\text { local geodiversity sites } \\
\text { Browne } 2012\end{array}$ & $\begin{array}{l}\text { Additional criteria for selecting } \\
\text { local geodiversity sites (Browne } \\
\text { 2012) }\end{array}$ & $\begin{array}{l}\text { Education value of selected } \\
\text { geodiversity sites (Brilha } \\
\text { 2016) }\end{array}$ & $\begin{array}{l}\text { Touristic value of selected } \\
\text { geodiversity sites (Brilha } \\
2016 \text { ) }\end{array}$ \\
\hline $\begin{array}{l}\text { 1. Representativeness } \\
\text { 2. Intergrity } \\
\text { 3. Rarity } \\
\text { 4. scientific knowledge }\end{array}$ & $\begin{array}{l}\text { 1. Educational } \\
\text { 2. Tourist value } \\
\text { 3. Historic value } \\
\text { 4. Aesthetic value }\end{array}$ & $\begin{array}{l}\text { 5. Threat to existence } \\
\text { 6. Uniqueness } \\
\text { 7. Biodiversity link } \\
\text { 8. Archaeological link } \\
\text { 9. Built heritage and rock art } \\
\text { 10. Cultural value } \\
\text { 11. Community use value } \\
\text { 12. Economic value (former use) } \\
\text { 13. Other designations }\end{array}$ & $\begin{array}{l}\text { - Didactic potential } \\
\text { - Geological diversity } \\
\text { - Accessibility } \\
\text { - Safety }\end{array}$ & $\begin{array}{l}\text { - Scenery } \\
\text { - Interpretative potential } \\
\text { - Accessibility } \\
\text { - Safety }\end{array}$ \\
\hline
\end{tabular}


covering more than $20 \mathrm{~km}^{2}$. The survey recorded mineral excavation sites (pitholes, adits, air shaft) and recent mineral collecting disturbances with an object number over 1000 . The results allow for much more detailed site classification and definition of the scope of final territorial and functional (e.g., development, protection) management priorities.

\section{Results}

\section{Site Selection and Identification}

The processing of NTM database regarding the detailed geological (1:25000), volcanological (1:10000), cultural landscape, and geoconservational mapping records resulted in an aggregated GIS database containing 2000 objects (Fig. 5). Data processing and selection were enhanced by our research group members who participated as experts in the former and ongoing field surveys. The primary selection of database identified sites from the preinventory. Four criteria sets of Brilha (2016) (representativeness, integrity, rarity, scientific knowledge) were applied to establish a potential site list of the NTM (Figs. 6 and 7).

The scientific research of the NTM has been carried out over more than two centuries. Intensive geological, volcanological, and mineralogical studies have identified several scientific hotspots in the region (e.g., Telkibánya, Komlóska, Füzéradvány). The ongoing research projects give international scientific relevance to some sites (e.g., Telkibánya lava domes, Fig 8e; Szepesi et al. 2019; Sinta peak mining pit field, Novák and Szepesi 2018; Fig. 8h, millstone quarry sites, Ésik et al. 2019). The rarity of NTM geoheritage is emphasized by geological and cultural landscape features as well. Large amount of glassy volcanic rocks (perlites) can be associated with Miocene lava domes and their volume is greatest here in the Carpathian Basin. The traditional perlite-related glasswork was started in the sixteenth century and the last factory was closed in 1921 . The medieval goldsilver mining area of Telkibánya contains 1-3 m-wide goldsilver bearing veins in hydrothermally altered andesite. Precious metals have been exploited here from the Middle Ages. Surface pitholes, underground adits (Fig. 8i), and air shafts give an exceptional density of mining heritage objects. Representativeness describes the suitability of the site to illustrate geological, cultural landscape features advancing engagements for the better understanding of the formation and evolution of the area. High representativity is usually associated with the geomorphological diversity, volcanology, hydrothermal alteration, and the related mining heritage. Large morphological objects and related historical heritage (medieval castles, ruins) are nationally recognized geoheritage features (Boldogkőváralja, Füzér, Regéc castle hills, e.g., Fig. $8 \mathrm{a}-\mathrm{c})$. Integrity is a crucial qualitative assessment point because the sites sometimes are highly modified under anthropogenic effects.

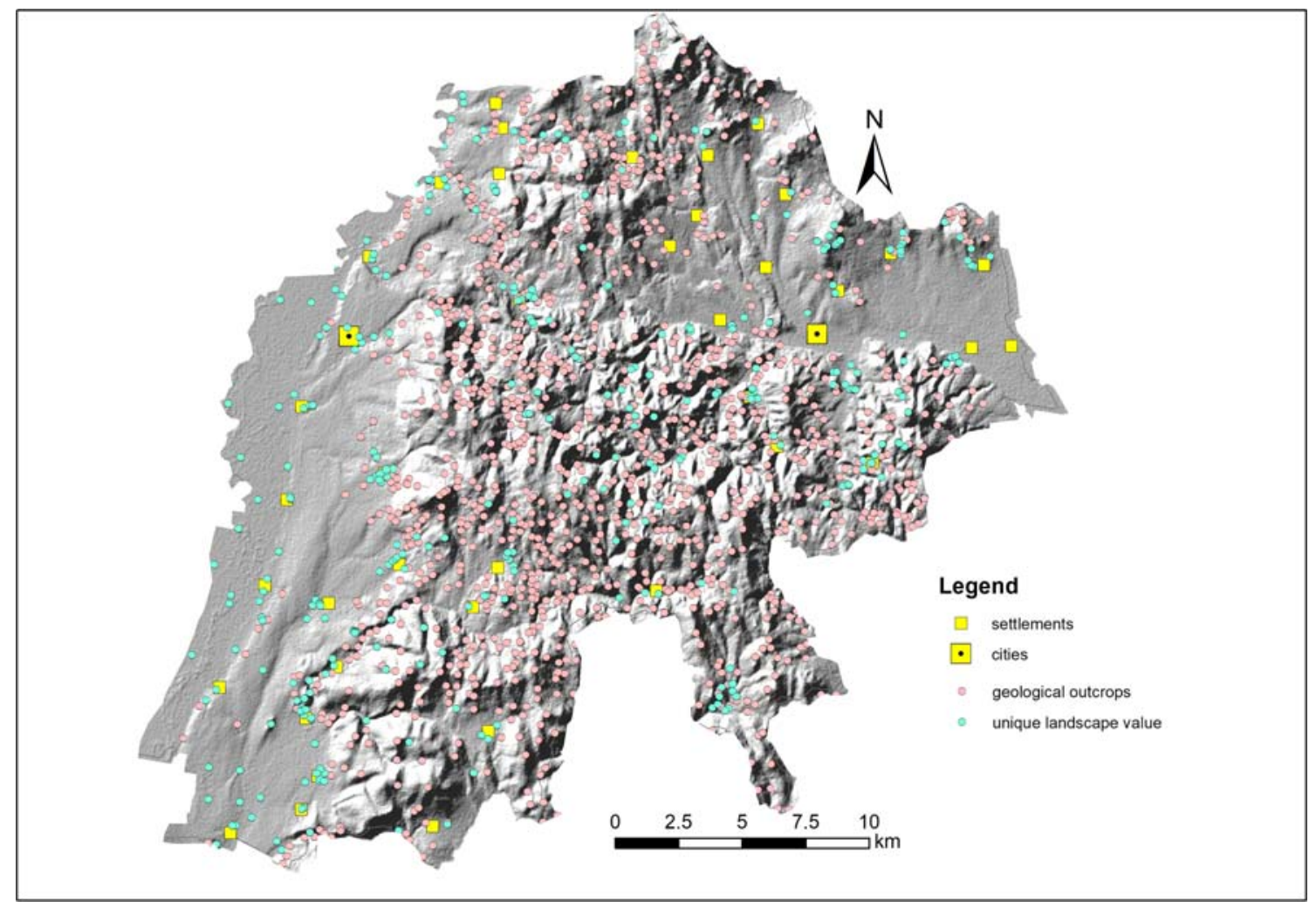

Fig. 5 Object database of the study area 


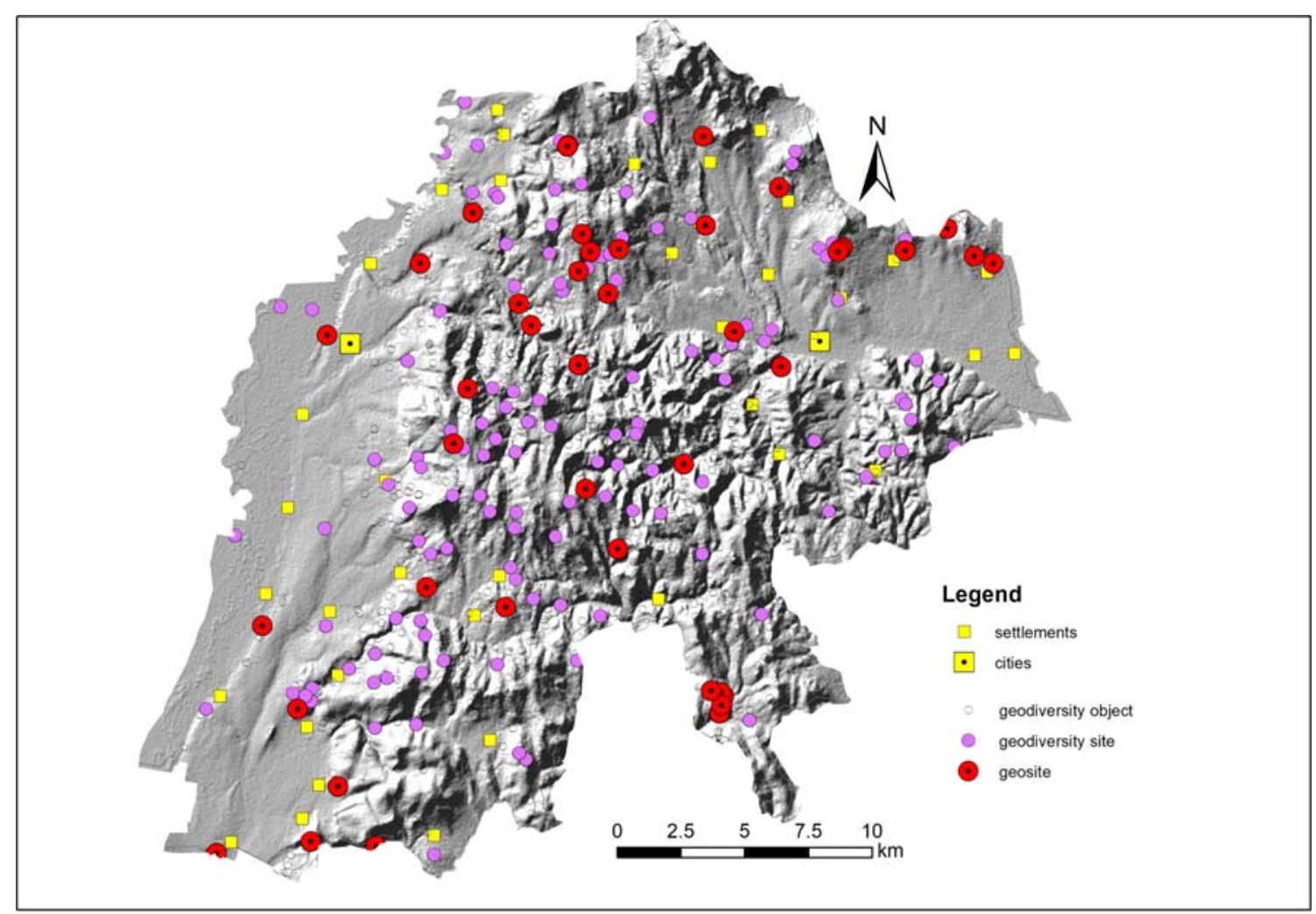

Fig. 6 Selected geosite, geodiversity sites with geodiversity objects

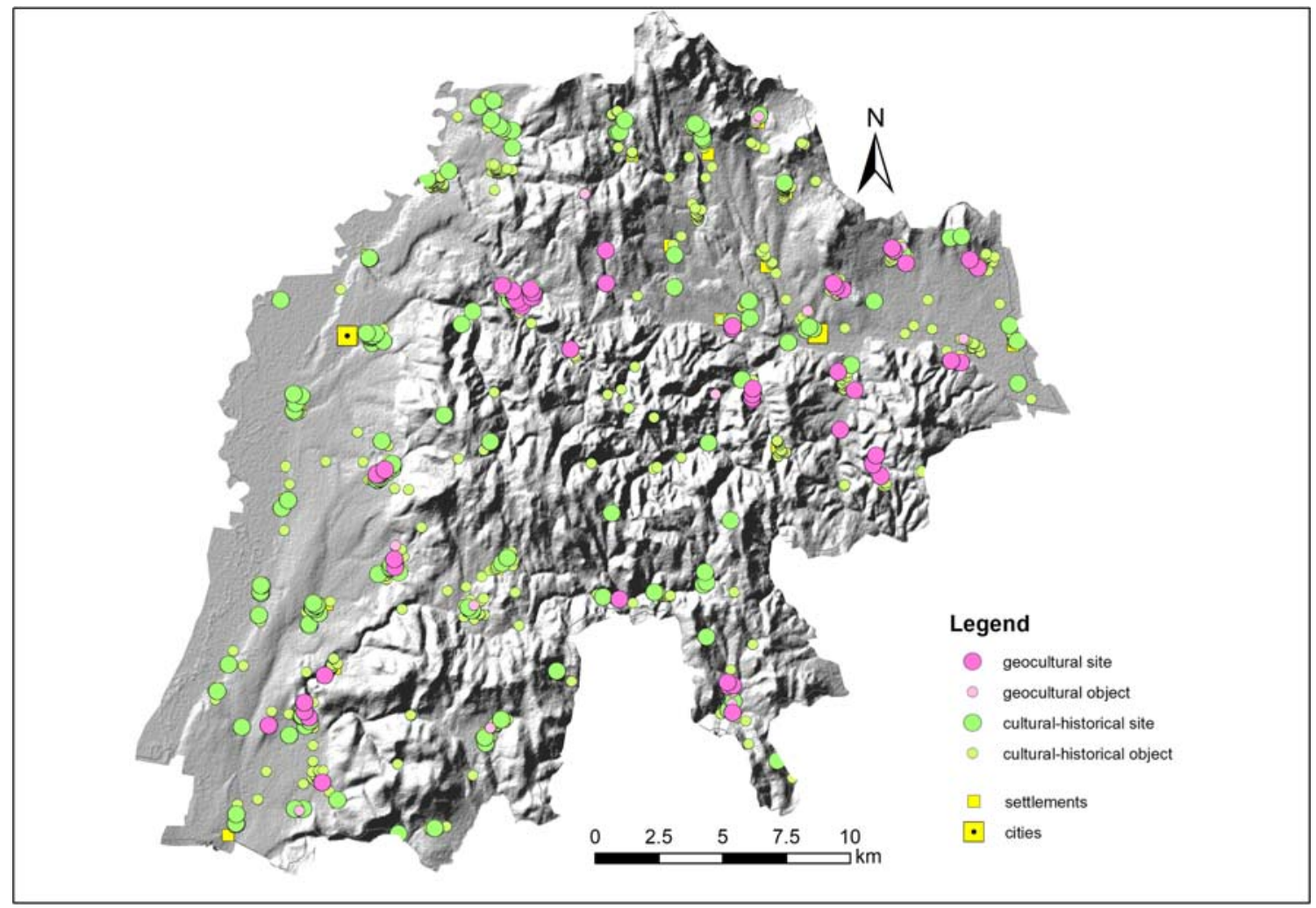

Fig. 7 Selected geocultural, cultural-historical sites with geocultural and cultural-historical objects 

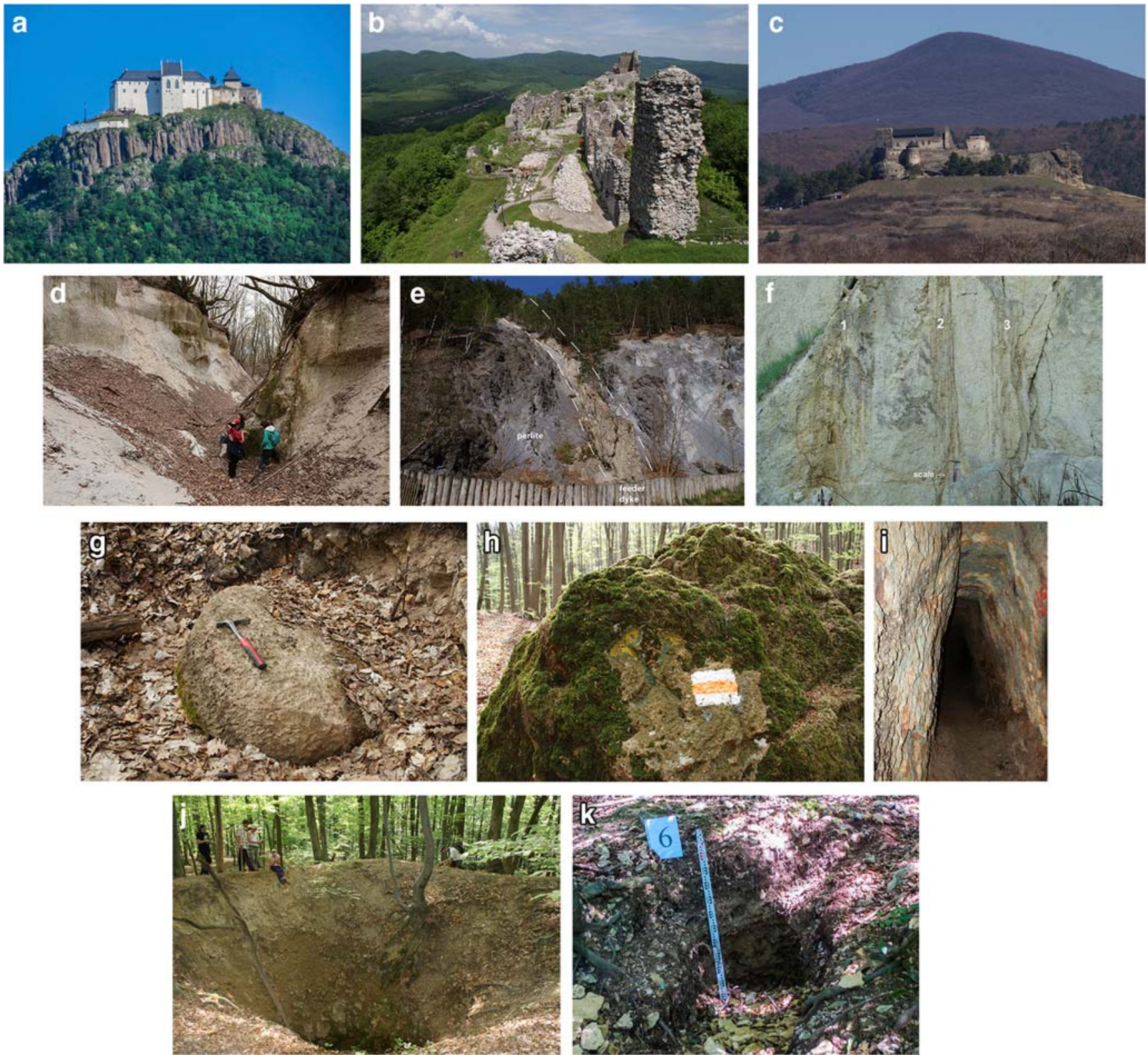

Fig. 8 Classification of geosites of the study area. Morphological objects

dome, Telkibánya, the structure was also described by volcanological mapping. Quarry: f, degassing pipes in ignimbrite, Vizsoly quarry, the site is protected by act 55/2015. g Millstone from medieval quarry excavated in silicified rhyolite tuff, Füzérradvány. Underground mine: h Radácsi stone (rhyolite) with painted mining symbol, along a hiking pathway (orange sign). An underground adit opened nearby. i Teréz adit, 500-m-long abandoned quarry, along a nature trail, Telkibánya, open-pit field. j Medieval open-pit hole excavating Au-Ag-containing veins, Joó Hill, Telkibánya. k Mineral collecting pit, Natura 2000 protected site, Király Hill, Telkibánya

The applied selection procedure identified 225 geodiversity-related sites (Figs. 6, 7, 8, 9, and 10) of which 175 was characterized as primarily geological features and described by geological and/or volcanological mapping. Narrowing down further, 58 sites were labelled as important mineralogical occurrences. The

remaining 50 identified sites emphasized important cultural relevance of the geological diversity. The largest part of the unique landscape value cadaster (920 object) was found as objects with local identity/cultural significance. Out of these, 180 were marked as culturalhistorical sites. 
Fig. 9 Geodiversity sites examples in the study area. a Andesite quarry,

Boldogkőváralja. b Rhyolitic tuff quarry, Bózsva. c Lookout tower, Jánosvára Hill, Kovácsvágás
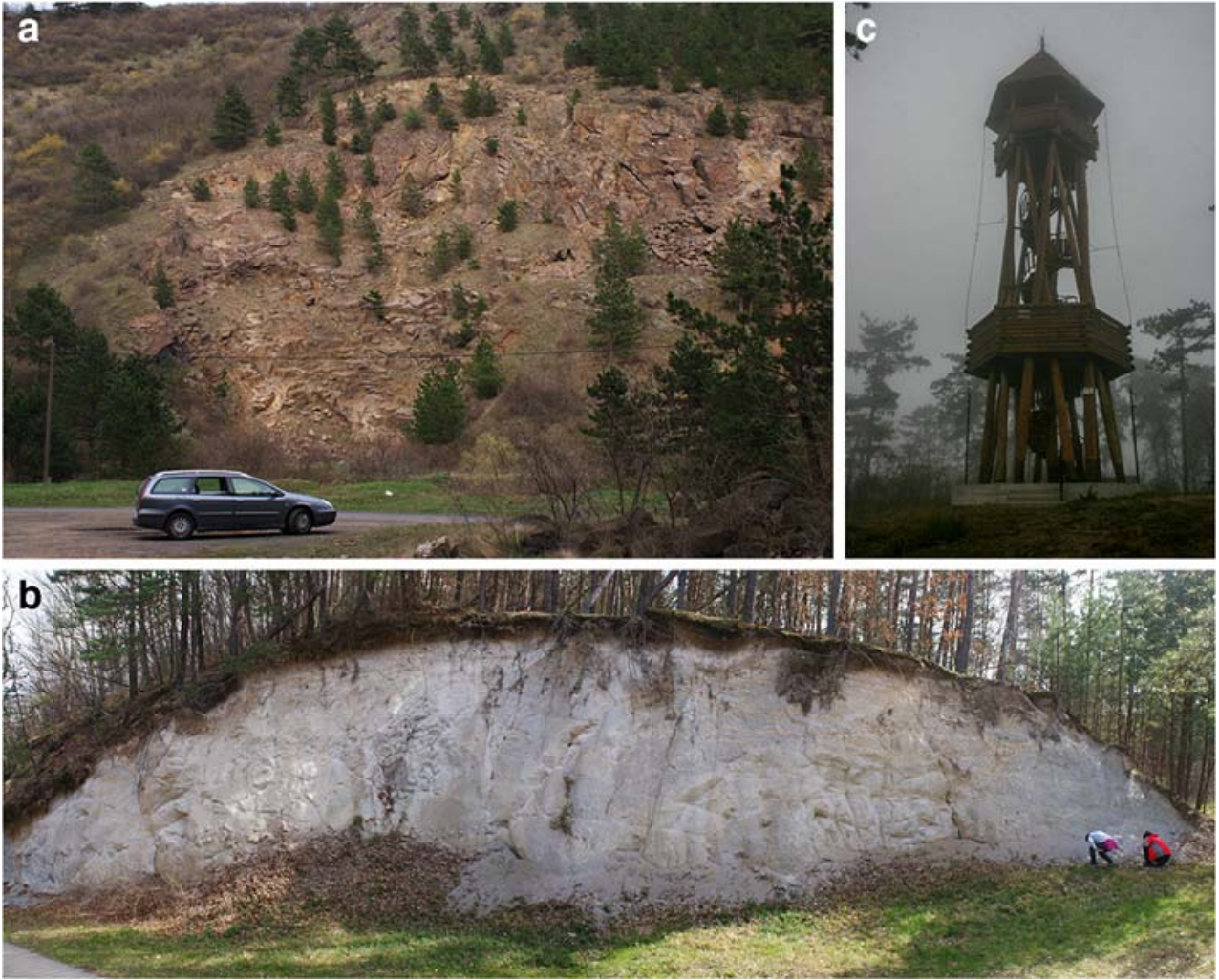

\section{Site Classification}

\section{Methodological Classification}

The classification procedure (Figs. 4 and 11) focused on the 225 geodiversity-related sites. The geological objects have a high value for scientific knowledge and they are marked as geosites (Figs. 6 and 8) in the sense of the conceptual framework proposed by Brilha (2016). In other cases when the sites have no exact scientific values but represent other interests (Table 3; educational, touristic, historic), they were defined as geodiversity sites (Fig. 9). Geocultural sites (Fig. 10) were
Fig. 10 Geocultural sites of the study area. a Garden of the Abaúj Museum, Telkibánya with millstone collection. b Glasswork manufactory building, Vágáshuta, see it on settlement heraldry Fig. 2d. c Multiple rows of cellars, Kovácsvágás. d Built water system of Szerencs stream
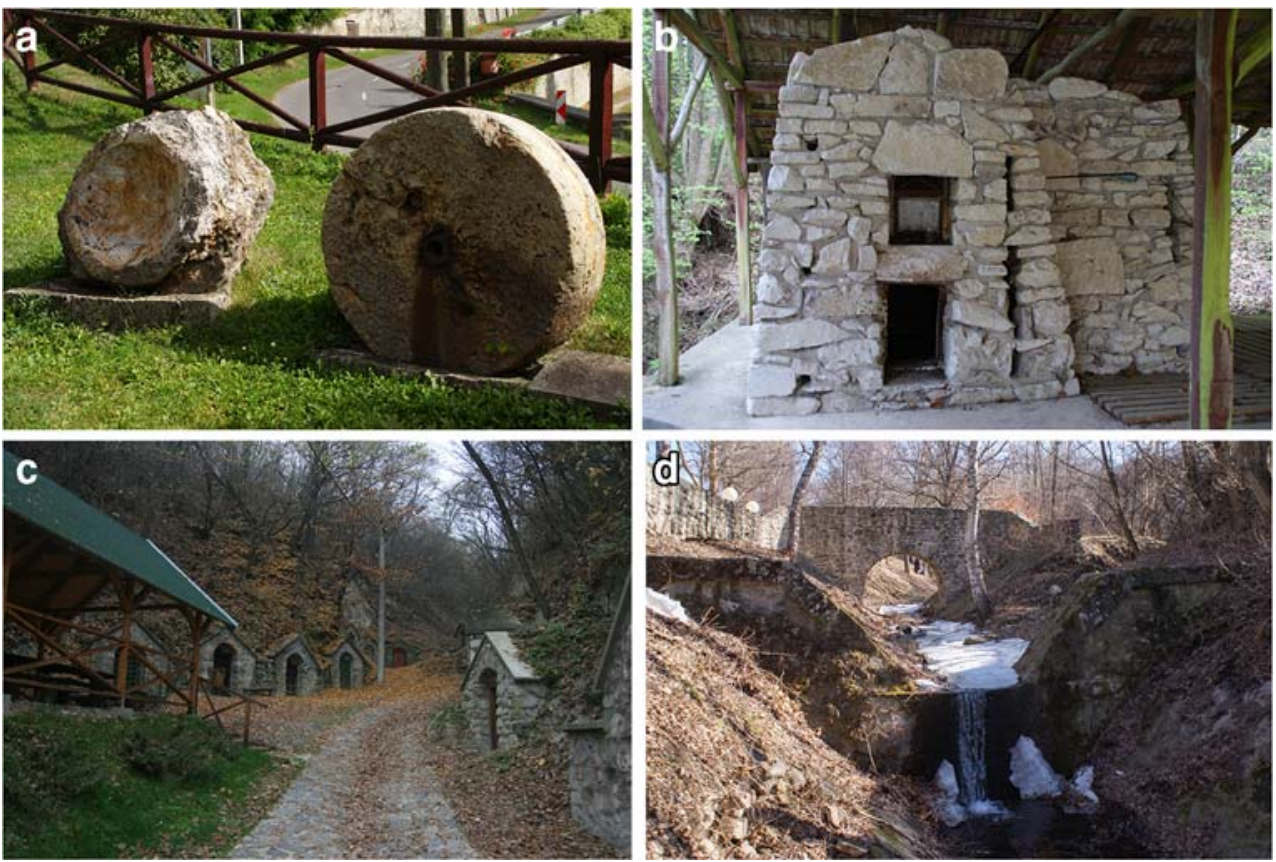
Fig. 11 Methodological classification of the geodiversity objects

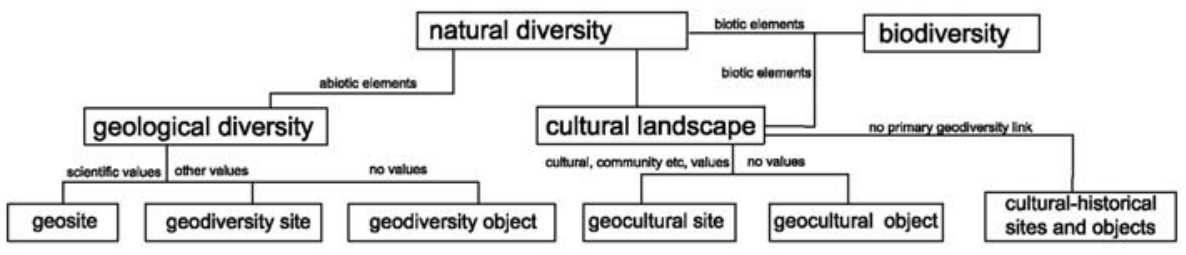

identified as special places where geoheritage features interact with cultural elements. Parameters from the additional criteria set of the local geodiversity sites (Browne 2012; Table 3; built heritage, cultural value) were found useful to select geocultural objects from the preinventory. These entities surveyed by unique landscape values cadaster (Fig. 7). Culturalhistorical sites (Fig. 11) are related to the cultural-historical development of the region and biodiversity was excluded from the final, geoheritage-based functional and thematic classification procedure.

\section{Functional Classification}

Functional classification refers to the physical nature of the site: e.g., extent, use, appearance. Geosites and geodiversity sites were classified into six major groups (Fig. 12; morphological object, outcrop, viewpoint, open pit field, quarry, underground mine). Morphological objects are largesized erosional forms (e.g., neck, lava dome) developed via long-term (10 Ma) denudation (Fig. 8a-c). The objects of fluvial erosion (canyon, river abrasion) were also classified here (Fig. 8d). Medium-sized periglacial landforms (cliff, blockmeer) are related to frost-induced hillslope evolution. Smaller natural rock occurrences were classified as outcrops (e.g., Fig. 8e). Periglacial cliffs usually served as natural viewpoint, but built lookouts were also considered for inclusion into this group. The natural morphology has been considerably modified by human activities. Anthropogenic landforms were classified as different types of quarrying. The largest rock excavations on the surface (up to $1 \mathrm{ha}$ ) were building stone and millstone (Fig. 8g; Ésik et al. 2019) quarries. The smaller surface holes $(\varnothing 3-10 \mathrm{~m}, \downarrow 0.5-6 \mathrm{~m})$ of gold-silver mining following ore containing hydrothermal veins were described as pit fields (Fig. 8j). Underground mines (Fig. 8i) with variable length $(10-500 \mathrm{~m})$ served the deeper excavation of hydrothermal veins (Telkibánya, Komlóska) and clay lenses (Füzérradvány).

Geocultural sites and objects (Fig. 10) were classified using the categories of the unique landscape cadaster (Table 2, and see the supplementary material for details). The major groups are mining-industrial heritage (Fig. 10a, b), and settlement-land use-related objects (cellars (Fig. 10c), built water systems (Fig. 10d), slope terraces). As special link between natural and cultural landscape 16 settlements contains carved wine cellars, even in multiple rows (Fig. 10c). Cultural-historical sites and objects represent the built heritage (churches, buildings, ruins, rural houses) and heritage stones (sculptures, gravestones) which also have additional geoheritage relevance.

\section{Thematic Classification}

Geosites (Fig. 8) and geodiversity sites (Fig. 9) were classified with the same thematic categories (Fig. 13). The sites with geomorphological interest contain objects with variable areal extent (up to 1 ha or larger; Fig. $8 \mathrm{a}-\mathrm{c}$ ) where younger geomorphological evolution resulted in a special transformation of landscape (uplift and rapid erosion). These are volcanic gorges with variable length, necks, lava domes, and periglacial cliffs. The sites with volcanological interest are the largest group containing relatively small objects $(<1$ ha; Fig. 8d-f) These are natural outcrops, road cuts, quarry sites with specific volcanological features as columnar jointing, special volcanic textures, volcaniclastic sedimentary records, and feeder dykes. Only one paleontological site was identified (Fig. 13). The third group, mining and industrial heritage (Fig. $8 \mathrm{~g}-\mathrm{j}$ ), represents the special link between geodiversity and cultural heritage and concentrated around three major areas: Telkibánya gold-silver mineralization, Füzérradvány, and Komlóska clays and ore mineralization. The mineral collection database (geomania.hu) also emphasized the role of epithermal mineralization in the mountains. These frequent resources were defined as mineralogical sites and are of special importance for the collectors. The fifth group is the viewpoint geosites which contains only panoramic viewpoints (Pereira and Pereira 2010; Migoń and Pijet-Migoń 2017) and not comprises observations points of the specific geosites. Usually these are associated with morphological sites to give unobstructed observation of the surrounding landscape. Manmade infrastructure usually attributed only to individual 


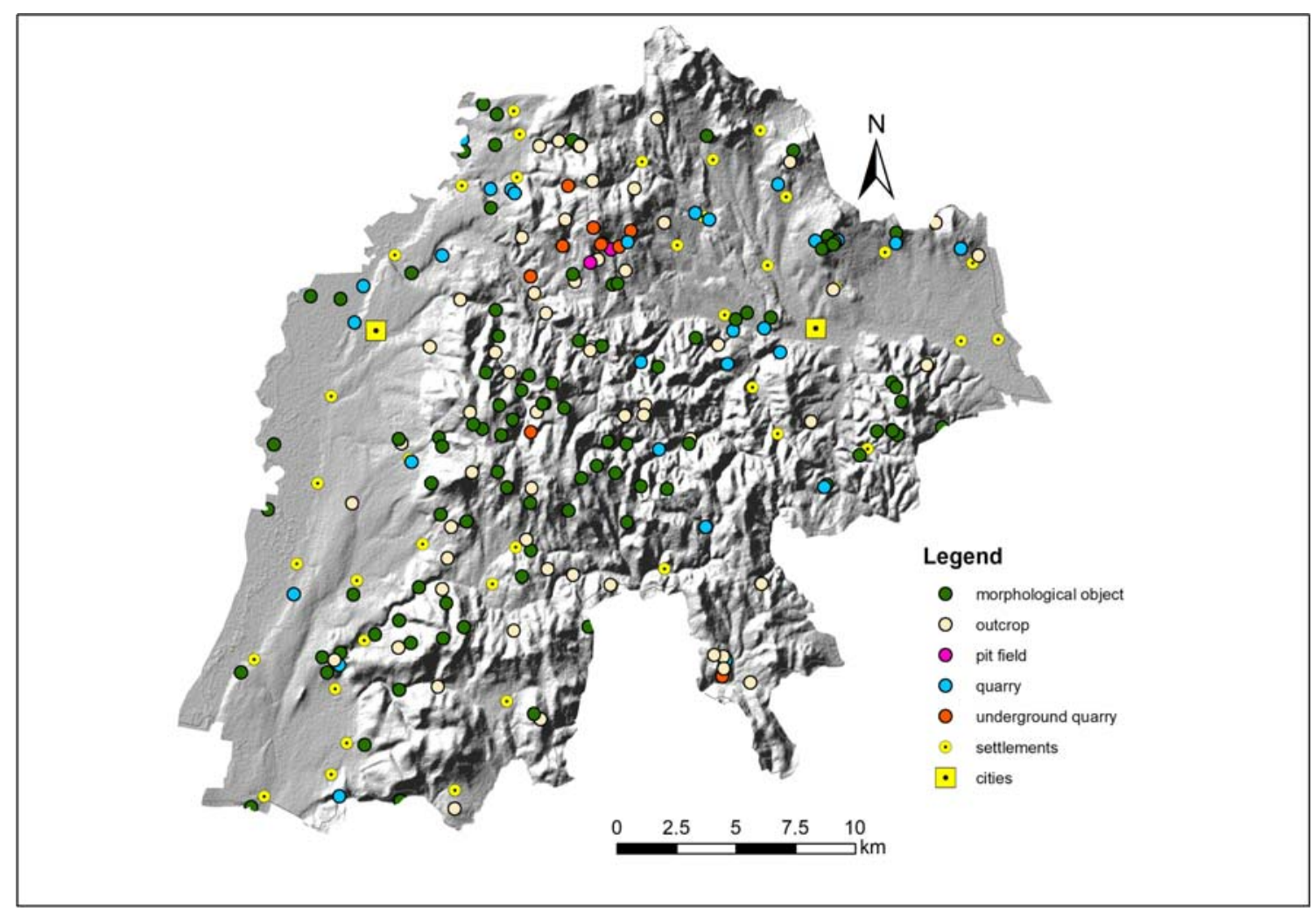

Fig. 12 Functional classification of the geosites and geodiversity sites

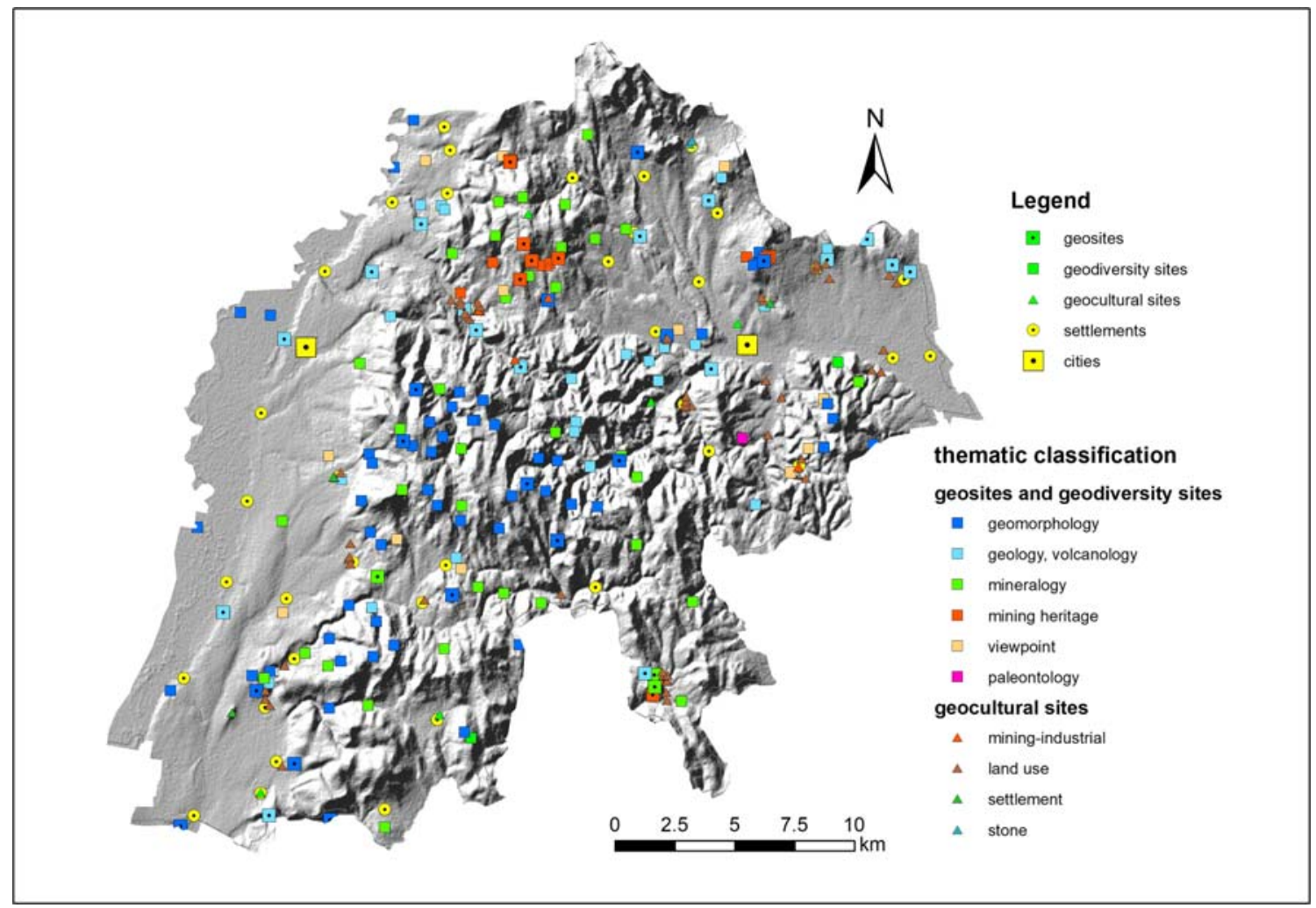

Fig. 13 Thematic classification of the geosites and geodiversity sites 
morphological forms (Fig. 8a-c). Geocultural sites (Fig. 10) also represent mining and industrial heritage. The gold-silver mining (buildings, ruins) and glasswork industry are the most important field because they connect geology and cultural landscapes. The most important building is the Abaúj Museum (former porcelain manufactory, Telkibánya) and its garden with a millstone collection (Fig. 10a). The special land use and settlement-related heritage (agriculture, water resources, townscape; Fig. 10b-d) is also related to geocultural heritage. The castle park of Füzérradvány is a Natural Monument (Table 1). Prehistoric and medieval hilltop fortification has been identified in several places (Fig. 8a-c).

\section{GIS Analysis of the Database}

The integration of the four databases into a preinventory was carried out on more than 2000 geodiversity objects (Fig. 5) featuring scientific research, cultural landscape diversity, and public geotourism interest in the study area. General object density varied between 0 and 8 object $/ \mathrm{km}^{2}$ (Fig. 14a) The different mapping objectives (Fig. 14b, c) showed different regional tendencies. The geology, volcanology objects including sites of mineral collecting concentrated in the high relief areas, which is the less populated, landscape protection area of the NTM (Fig. 14b). Average object density is over $4-5$ sites $/ \mathrm{km}^{2}$, while this number decreased to 1 site $/ \mathrm{km}^{2}$ in the intramontane Hegyköz Basin and Hernád Valley area. In contrast, the cultural landscape-related unique landscape values concentrated mainly in the surroundings of the settlements (Fig. 14c). Object density is only up to half that of the geological sites $\left(3\right.$ sites $\left./ \mathrm{km}^{2}\right)$. Some settlement shows remarkable density of sites (Telkibánya, Füzérradvány, Fony, Komlóska), where geology-related landscape values are coupled with special land use and community values. After the selection procedure, 220 potential geosites, geodiversity, and geocultural sites were identified (Figs. 12 and 13). Geodiversity hotspot regions represent a density above 3 sites $/ \mathrm{km}^{2}$ (Fig. 14d) and are related to 3 settlements (Telkibánya, Füzérradvány, Komlóska). Other moderate density regions (2-3 sites/ $\mathrm{km}^{2}$ ) can be associated with 4 other settlements. As can
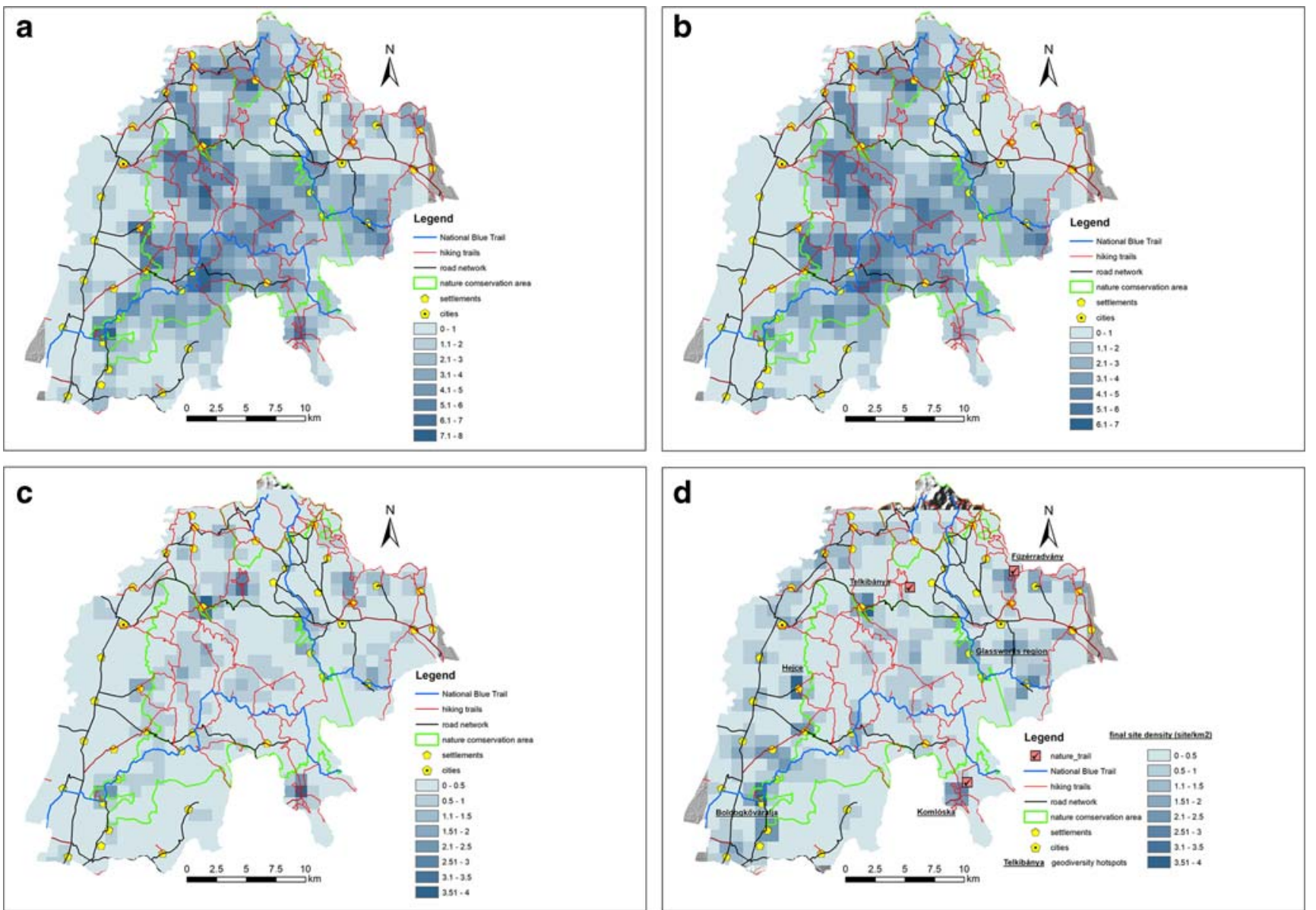

Fig. 14 a Preinventory density of database (outcrop $\left./ \mathrm{km}^{2}\right)$. b Preinventory density of the geological outcrops ( $\left.\mathrm{sites} / \mathrm{km}^{2}\right)$. $\mathbf{c}$ Preinventory density of the unique landscape values(sites $/ \mathrm{km}^{2}$ ). $\mathbf{d}$ Density of the final database including geosites, geodiversity, and geocultural sites $\left(\mathrm{sites} / \mathrm{km}^{2}\right.$ ) 
be seen in Fig. 14a-d, hiking trails pass through higher density regions.

\section{Discussion}

\section{Geodiversity in a Cultural Landscape}

There is an increasing interest on geodiversity and geoheritage studies worldwide that have a generated high number of inventory studies in recent years. The major purpose of these studies was to create a regional (sometimes as part of a national) inventory that directs management priorities to geoconservation or geotourism (Wimbledon 1999; FuertesGutiérrez and Fernández-Martínez 2010; Kubalíková 2013; Gatley and Parkes 2018; Guimarães et al. 2018; Zangmo et al. 2020). A large number of geoheritage studies focused on compiling regional databases and inventories (FuertesGutierrez and Fernandez-Martinez 2012; de Lima et al. 2010; Mauerhofer and Reynard 2018). Most of these studies focused on the identification and assessment of geosites that are based on literary review and extensive cartography work, but only a few studies involved cultural landscape objects in the assessment (Brilha 2016; Arruda et al. 2017; Szepesi et al. 2017; Kubalíková 2019). Although Reynard and Giusti (2017) discussed the landscape and cultural value of geoheritage, the lack of case studies on cultural landscapes that would use a comprehensive object database that includes natural and cultural geoheritage was found. The cultural landscape is a social construction, a mix of tangible (geodiversity, biodiversity) physical and anthropogenic and intangible features (emotions, aesthetics, senses, symbols, phenomena, individual feelings, social representations; Reynard 2009). In the past few decades, the negative trends raised concerns among practitioners about the resulting loss of diversity especially in the case of traditional rural landscapes (Di Fazio and Modica 2018; Lakner et al. 2018). Our results verify that the identification, interpretation, and characterization of geoheritage elements are fundamental to define sustainable management strategies and strengthen local identity.

In Hungary, landscape-related research has a long tradition (e.g., Marosi 1985; Lóczy 2002). These studies emphasized that there were rapid societal changes in rural regions due to urbanization and related migration in the twentieth century. The traditional cultural landscapes suffered a great loss in diversity, integrity, and identity. Nature and landscape protection activities have addressed this issue with introducing the definition of unique landscape values that established a new Hungarian standard (MSZ 20381:2009, see the supplementary material) and a national initiative (TÉKA, Kiss 2011). This survey included objects of natural geodiversity but the largest object number was related to cultural landscapes.
Unfortunately, it does not cover the whole country but the study area provided full processing (Fig. 5).

The analysis of the Tokaj Wine Region Historic Cultural Landscape (Szepesi et al. 2017) used Brilha's (2016) proposal to classify the selection into two separated groups (geosite and geodiversity site). The more thorough analysis of the study area indicated the involvement of new categories in order to include cultural landscape elements (Reynard and Giusti 2018; Fig. 11). The basic unit of inventory is the object, which is an abiotic part of the landscape. The representativeness, integrity, rarity, and scientific knowledge (Table 3) highlighted objects as geosites which are potential features for a national thematic inventory (Figs. 6 and 8). Other natural objects with high touristic, educational values got classified as geodiversity sites (Figs. 6 and 9) which exhibit geological diversity on a regional or local scale (Table 3 ). Using the unique landscape cadaster, the objects of cultural landscape included in the inventory were classified with the same approach (Fig. 7). If a cultural heritage object had a geodiversity relevance, then it was defined as a geocultural site (Reynard and Giusti 2018). These are industrial buildings, ruins, and cellars, mostly representing a regional or local level of importance (Fig. 10). The items of local cultural identity, history, and religion defined as cultural-historical sites, while the common elements (heritage stones, cellars) were defined as common cultural-historical objects. The last two categories also emphasized the geoheritage link because heritage stones and buildings were usually built form local stones but their primary relevance was outside of pure geodiversity interest (Carreras and Druguet 1999).

\section{Geoconservation Issues}

The surveyed objects of geodiversity are very diverse. It appears in different properties (Fig. 14, Table 4) like the extent of the resource, functional character with current use, and geographical setting (e.g., population density, nature conservation areas). Their geoconservation possibilities are highly determined by local circumstances and priorities (Prosser et al. 2017). The study area is part of the Zemplén Landscape Protection Area (protected by general law 1996 LIII; Fig. 1, Table 1) which declared a prohibition on causing damage on geodiversity (see the supplementary material) but it does not specify a real site-based protection. During the last decade, a new legal framework addressed the conservation of geological heritage in Hungary with territorial protection of individual geosites (Szepesi et al. 2018a). Acts 13/1991 and 55/ 2015 (Table 1, supplementary material) define types of protected geosites (stratotype section, outcrop). Based on these acts, 25 sites were protected as individual natural monument and other 18 sites declared as protected stratotype sections or geological formation area within 
Table 4 Site management features of the major methodological and thematic groups regarding conservation and geotourism issues

\begin{tabular}{|c|c|c|c|c|c|c|}
\hline Type & Categories & Appearance & $\begin{array}{l}\text { Integrity, } \\
\text { vulnerability }\end{array}$ & Protection & $\begin{array}{l}\text { Current } \\
\text { geotourism } \\
\text { infrastructure }\end{array}$ & Management issues \\
\hline \multirow[t]{6}{*}{$\begin{array}{l}\text { Geosites and } \\
\text { geodiversity } \\
\text { sites }\end{array}$} & $\begin{array}{l}\text { Sites with } \\
\text { volcanological } \\
\text { interest }\end{array}$ & $\begin{array}{l}\text { Natural outcrops, } \\
\text { quarries, road } \\
\text { cuts }\end{array}$ & $\begin{array}{l}\text { Vegetation cover, } \\
\text { illegal waste, } \\
\text { mineral collection. } \\
\text { building } \\
\text { construction in } \\
\text { quarry yard }\end{array}$ & $\begin{array}{l}\text { Zemplén } \\
\text { Landscape } \\
\text { Protection } \\
\text { Area Vizsoly } \\
\text { Rhyolite Tuff } \\
\text { Quarry } \\
(13 / 1991)\end{array}$ & $\begin{array}{l}\text { Thematic nature } \\
\text { trails } \\
\text { (Füzérradvány) } \\
\text { interpretative } \\
\text { panels }\end{array}$ & $\begin{array}{l}\text { Quarry wall safety, collection } \\
\text { permit, development of } \\
\text { technical infrastructure, tour } \\
\text { guides, more interpretative } \\
\text { panel }\end{array}$ \\
\hline & $\begin{array}{l}\text { Sites with } \\
\text { geomorphologi- } \\
\text { cal interest }\end{array}$ & $\begin{array}{l}\text { Eroded volcanic } \\
\text { cones coupled } \\
\text { with cultural } \\
\text { heritage } \\
\text { (castles) } \\
\text { periglacial } \\
\text { cliffs, valleys }\end{array}$ & $\begin{array}{l}\text { Ground and } \\
\text { vegetation } \\
\text { disturbances on } \\
\text { hilltop fortification } \\
\text { reconstruction, } \\
\text { rock falls in } \\
\text { valleys }\end{array}$ & $\begin{array}{l}\text { Zemplén } \\
\text { Landscape } \\
\text { Protection } \\
\text { Area Nature } \\
\text { Conservation } \\
\text { Areas, Natural } \\
\text { Monument }\end{array}$ & Hiking pathways & $\begin{array}{l}\text { Steep wall safety in volcanic } \\
\text { gorges technical } \\
\text { infrastructure at terrain steps } \\
(<2 \mathrm{~m}) \text {, hiking pathways } \\
\text { improvement, expert (or } \\
\text { educated) field guide }\end{array}$ \\
\hline & $\begin{array}{l}\text { Industrial } / \text { mining } \\
\text { heritage }\end{array}$ & $\begin{array}{l}\text { Underground } \\
\text { mines, open-pit } \\
\text { fields }\end{array}$ & $\begin{array}{l}\text { Ground excavation } \\
\text { disturbances by } \\
\text { mineral collectors, } \\
\text { underground mine } \\
\text { instabilities, } \\
\text { open-pit filling }\end{array}$ & $\begin{array}{l}\text { Filed survey } \\
\text { connected to } \\
\text { Decree } \\
15-2015\end{array}$ & $\begin{array}{l}\text { Thematic nature } \\
\text { trails } \\
\text { (Telkibánya, } \\
\text { Komlóska, } \\
\text { Füzzéradvány), } \\
\text { hiking path } \\
\text { interpretative } \\
\text { panels }\end{array}$ & $\begin{array}{l}\text { Surface and underground safety } \\
\text { facilities, digital } \\
\text { interpretation content, policy } \\
\text { against mineral excavation }\end{array}$ \\
\hline & $\begin{array}{l}\text { Viewpoint } \\
\text { (natural) }\end{array}$ & $\begin{array}{l}\text { Natural cliffs, } \\
\text { mountaintops }\end{array}$ & Vegetation growth & $\begin{array}{l}\text { Zemplén } \\
\text { Landscape } \\
\text { Protection } \\
\text { Area }\end{array}$ & Hiking pathways & $\begin{array}{l}\text { Vegetation removal, building } \\
\text { reconstruction, landscape } \\
\text { interpretation features }\end{array}$ \\
\hline & Viewpoint (built) & $\begin{array}{l}\text { Natural and built } \\
\text { viewpoints }\end{array}$ & Vegetation growth & $\begin{array}{l}\text { Zemplén } \\
\text { Landscape } \\
\text { Protection } \\
\text { Area }\end{array}$ & Hiking pathways & $\begin{array}{l}\text { Vegetation removal, building } \\
\text { reconstruction, landscape } \\
\text { interpretation features }\end{array}$ \\
\hline & $\begin{array}{l}\text { Mineralogy, } \\
\text { paleontology }\end{array}$ & $\begin{array}{l}\text { Natural outcrops, } \\
\text { quarries, }\end{array}$ & $\begin{array}{l}\text { Mineral and fossil } \\
\text { collection }\end{array}$ & $\begin{array}{l}\text { Zemplén } \\
\text { Landscape } \\
\text { Protection } \\
\text { Area }\end{array}$ & $\begin{array}{l}\text { Thematic nature } \\
\text { trails, hiking } \\
\text { pathways }\end{array}$ & $\begin{array}{l}\text { Site-based protection and } \\
\text { control }\end{array}$ \\
\hline \multirow[t]{3}{*}{ Geocultural sites } & Mining-industrial & $\begin{array}{l}\text { Ruins of } \\
\text { buildings, } \\
\text { water } \\
\text { management, } \\
\text { glasswork } \\
\text { buildings }\end{array}$ & $\begin{array}{l}\text { Natural degradation, } \\
\text { collapse, } \\
\text { vegetation cover }\end{array}$ & $\begin{array}{l}\text { Zemplén } \\
\text { Landscape } \\
\text { Protection } \\
\text { Area }\end{array}$ & $\begin{array}{l}\text { Thematic nature } \\
\text { trails, hiking path } \\
\text { interpretative } \\
\text { panels }\end{array}$ & $\begin{array}{l}\text { Vegetation removal, building } \\
\text { reconstruction, industrial } \\
\text { interpretation features }\end{array}$ \\
\hline & Land use & $\begin{array}{l}\text { Traditional } \\
\text { agriculture, } \\
\text { forestry }\end{array}$ & Vegetation growth & $\begin{array}{l}\text { Zemplén } \\
\text { Landscape } \\
\text { Protection } \\
\text { Area }\end{array}$ & $\begin{array}{r}\text { Usually not } \\
\text { involved }\end{array}$ & $\begin{array}{l}\text { Sustainable landscape } \\
\text { management }\end{array}$ \\
\hline & Settlement & $\begin{array}{l}\text { Castle parks, } \\
\text { cellars rows, } \\
\text { traditional } \\
\text { village } \\
\text { architecture, } \\
\text { water } \\
\text { management }\end{array}$ & $\begin{array}{l}\text { Natural degradation } \\
\text { collapse }\end{array}$ & $\begin{array}{l}\text { Füzérradvány } \\
\text { Castle Park } \\
\text { Natural } \\
\text { Monument }\end{array}$ & $\begin{array}{l}\text { Thematic nature } \\
\text { trails, hiking path } \\
\text { interpretative } \\
\text { panels }\end{array}$ & $\begin{array}{l}\text { Regulations of the Office for } \\
\text { Construction and Heritage, } \\
\text { tour guides and training } \\
\text { related to geoheritage } \\
\text { interpretation }\end{array}$ \\
\hline $\begin{array}{l}\text { Cultural-historical } \\
\text { sites }\end{array}$ & $\begin{array}{l}\text { Cultural landscape } \\
\text { diversity }\end{array}$ & $\begin{array}{l}\text { Churches, castles, } \\
\text { ruins, bridges, } \\
\text { memorial sites }\end{array}$ & $\begin{array}{l}\text { Various condition } \\
\text { from scattered } \\
\text { ruins to full } \\
\text { reconstruction of } \\
\text { medieval castles }\end{array}$ & $\begin{array}{l}\text { Protection of } \\
\text { historical } \\
\text { buildings }\end{array}$ & $\begin{array}{l}\text { Reconstruction, } \\
\text { preservation } \\
\text { activities }\end{array}$ & $\begin{array}{l}\text { Geoheritage-related } \\
\text { development and } \\
\text { interpretation, cooperation of } \\
\text { with the cultural heritage } \\
\text { operators, owners, } \\
\text { municipalities, and national } \\
\text { park }\end{array}$ \\
\hline
\end{tabular}

protected natural areas (e.g., national parks, landscape protection areas) in Hungary in 2015. National Park
Directorates recently launched a preinventory survey of vulnerable sites, targeting more than 40 sites in the study 
area but only one (Vizsoly Rhyolitic Tuff quarry, Fig. 8f; Szepesi et al. 2015) got territorial protection as natural monument (Tables 1 and 4).

The physical nature of the sites is also important in geoconservation, as geosites of a similar physical nature are likely to be subject to similar threats and require similar conservation management (Prosser et al. 2017). The functional classification (Fig. 9a; morphological sites, outcrop, pit fields, quarry, underground mine) was based on that and was useful to define specific conservation management priorities. Field surveys defined the vulnerability of the sites with the detection of the level of anthropogenic activity and deterioration of the geological elements. Even though, the geosites were recognized as on the one hand natural and on the other hand man-made outcrops (quarry, road cuts), their integrity was still highly inconstant. The sites have been recently degraded by only natural processes. There are only two recently operating quarries, but the related safety problems were excluded from the final geosite designation. The rest of the quarries are abandoned in various conditions. Sometimes the debris along the walls got forested, disturbing the observation of geological elements. In a special case, a hotel was built in the yard of the largest quarry forming a physical barrier against observation. Sometimes quarries are filled with municipal waste but thanks to conservation efforts remediation is taking place in most cases. Mining heritage (quarries, Fig. $8 \mathrm{~g}-\mathrm{j}$ ) is a special type of the cultural landscapes (Mata-Perelló et al. 2017; Prosser 2018). Mining activities ceased from the eighteenth century (gold-silver mining) up to present times (clays, Füzérradvány) with the depletion of stock. The natural degradation of surface landforms is common due to natural filling of the pitholes and the collapse of underground infrastructure. As a special intersection of the nature conservation and geotourism, there is renewed interest about minerals and fossils (Szepesi et al. 2018; Ruban 2019; Timothy and Witt 2019). From the study area, 59 sites have been described in the mineral collecting database (geomania.hu). The field surveys observed intensive illegal mineral excavation in several places (e.g., Fig. 8k). Although the act (1996 LIII, see the supplementary material) declared possible protection of significant minerals and fossils, it is still an unresolved task for nature conservation organizations. Pit holes and underground mines are the most affected objects. Some mineral species got almost completely removed from natural occurrences (garnet, Kis-Sertés-hegy). In the case of scientific research, certain minerals have to be bought from the collectors for further laboratory investigation. The fact that the previously mentioned regulation 2015/55 (see supplementary) controls mineral or rock-collecting activities (community or private) including possibilities of scientific research is an important result in recent years.

\section{Geotourism and Geoeducation}

In the past few years, significant progress has been achieved in geotourism in Hungary. Nowadays, there are hundreds of nature trails in Hungary; in many cases, geosites and geocultural sites are the main attractions (Horváth and Lóczy 2015). The importance of geotourism is also emphasized by the acceptance of two geoparks as members of the European and Global Geoparks Network and the opening of the Kemenes Volcano Park (Szepesi et al. 2017). One of them, the Nógrad-Novohrad geopark (Horváth and Csüllög 2013), was developed in frontier, peripheral location along the Hungarian-Slovakian border in an economically disadvantaged environment. The current NTM case is very similar, but various activities have been undertaken in the last decade to increase regional destination visibility. From a geoheritage management perspective, the study area belongs to the Aggtelek National Park Directorate which is also responsible for the two UNESCO World Heritage Sites (Fig. 1). The caves of the Aggtelek and Slovak Karst (Telbisz et al. 2020) are declared as natural, while the Tokaj Wine Region Historic Cultural Landscape as a cultural heritage site (Szepesi et al. 2017). This case also indicates disadvantages in the regional site management priorities.

The special landscape character arises from the interplay of physical and cultural elements as many geosites have strong archeological and historical connections (Fig. 8a-c). Our survey identified 220 sites (geosites, geodiversity, geocultural) in the study area highlighting the importance of natural and cultural landscape values for the development of geotourism. In Table 4, the management features of the major methodological and thematic groups regarding conservation and management issues are summarized. Quality interpretation is essential for raising awareness about geoheritage values but visitor centers operating at the cultural heritage sites showed poor visibility of volcanic geoheritage and improper management of the individual sites.

Although geoheritage is not a well-understood concept, some geosites have long been used in tourism (Fig. $8 \mathrm{~g}-\mathrm{j}$ ). Also there are recently recognized objects (rhyolitic tuff gorge of Abaújvár, Ésik and Szepesi 2017; Fig. 8e). The current geotourism infrastructure is represented by only thematic nature trails and hiking routes. In the last decades, three thematic nature trails were established and they continue to serve regional geoeducation (Table 4). These trails raise awareness to three major mining areas (Füzérradvány, Komlóska Telkibánya), The final site density map (Fig. 14d) also highlighted these geodiversity hotspots. The trails connect known geosites and geodiversity sites but as our study shows they also include geocultural and cultural sites/objects. The Füzérradvány and Komlóska trails were constructed during the 1990s as self-guided thematic routes (Kiss et al. 1999; Kiss 
et al. 2002). Unfortunately, the field infrastructure shows deterioration and the interpretation facilities need more development to increase tourism activity. The PHARE cross-border cooperation project related to gold-silver mining heritage established an environmental geotechnical educational center (Telkibánya) which is suitable for organizing special short-term courses and educational field trips (Hartai and Németh 2012). Another target is primary education with special outdoor school programs teaching geo- and biological diversity. The sites are where the volcanic geomorphology associated with cultural heritage (castles, ruins) has a particular importance. Some recent regional cultural identity-related tourism development projects were therefore established. The ruins of the hilltop fortification castles on eroded volcanic landforms have been renovated or are under construction (Füzér, Boldogkőváralja, Regéc). Beside the debated reconstruction (ICOMOS Hungary 2017) on cultural heritage, the adequate interpretation of volcanic processes and geomorphology is completely missing which would be essential for raising awareness about geoheritage (Migoń and PijetMigoń 2016; Zangmo et al. 2017). These exhibition sites are operating with local staff members without geoeducation knowledge. Involving them into special geoheritage-related training would also have high relevance in geodiversity popularization.

The final density map (Fig. 14d) is also drawing attention to other settlements with some potential in geoheritage development. The region of the glassworks (Figs. 9 and 10) and the village of Hejce are also providing possibilities to emphasize the role of geo- and cultural diversity. The hiking trails also found to be passed through higher density regions (Fig. 14a-d). The National Blue Trail $(1165 \mathrm{~km})$ was selected into the ten best trips to take in 2020 in the world by the National Geographic magazine (nationalgeographic.com). The $100-\mathrm{km}$-long section of the trail connects many geosite, geodiversity, and geocultural sites which presents a unique opportunity for future site-based developments (interpretation, infrastructure).

\section{Conclusions}

The inventory and site assessment are essential steps in different scales of geoconservation and also in the establishment of the priorities in site management (e.g., in geoparks). In Hungary, regional databases regarding the natural and cultural heritage (geology, geoconservation) contributes to the extension of the regional inventories with large number of geodiversity-related records. The combination of a specific selection procedure and the assessment fieldwork resulted in the final list of potential geosites, geodiversity, and geocultural sites. The final 60 geosites with a total area of $700 \mathrm{~km}^{2}$ well represent the geological history of the study area, while another 160 geodiversity and geocultural sites emphasize further potential in natural and cultural diversity. The site designations are not definitive categories. Further scientific research or increased geotourism/educational interest eventually bring sites to a higher status: object $\rightarrow$ geodiversity site, geodiversity site $\rightarrow$ geosite. This inventory is a preliminary work and essential for understanding the regional cultural landscape heritage. Many European countries have a national geosite inventory (Czech Geological Survey 2014; Geological Survey of Spain 2014) which resulted from nature and landscape protection legislations. In Hungary, the applied methodology allows the detailed evaluation of the registered sites. The practice can be extended to compile a state-level comprehensive national inventory.

The inventory and the result of a preliminary assessment are also suitable for defining spatial planning and geoconservation strategies. In a regional context, the density analysis identified areas as geodiversity hotspots. Currently, the volcanic geoheritage values of the study area are not enough to initiate and maintain long-term regional geotourism. The infrastructure needs improvement directly in site accessibility and integrity to emphasize the representativeness of the geological features. The continuous improvement of field and museum interpretation is important for visitor satisfaction. The current (geo)tourism flow is partly connected to neighboring Slovakian areas because of the frontier location of Kosice, the second largest city of Slovakia. Cross-border projects are important to further improve the quality of the basic infrastructure. Future geotourism development should be focused on the improved collaboration among scientific research, local municipalities, and tourism companies. The presented classifications fulfill the requirements regarding geoheritage in the guidelines and criteria for national geoparks organized by the Global Geopark Network (UNESCO 2014; Brilha 2017) with the list and description of geological and cultural sites.

Mineral-collecting activities emphasize conflicts between geotourism and geoconservation and underline the importance of site-based protection and continuous control on geotourism-based disturbances. The geoconservation-based assessment surveyed 50 sites and pinpointed the strategies vital for further protection. During this process, only one site was under legal protection but further explicit site protection measures are being prepared.

Acknowledgments The first author as a chairman of Hungarian Geological Society, ProGEO Section on conservation of the geological heritage would like to thank the ProGEO community for the fruitful 
discussions. We also thank the Aggtelek National Park for providing the database of unique landscape cadastre. Additional fieldwork and qualitative assessment are related to the $\mathrm{PhD}$ study of Z. Ésik at the University of Debrecen.

Funding This research has been funded by the FK131869 project of the National Research Development and Innovation Office (Hungary). The work was also supported by the European Union and the State of Hungary, co-financed by the European Regional Development Fund in the project of GINOP-2.3.2-15-2016-00009 'ICER'.

\section{References}

Arruda KEC, Garcia MGM, Del Lama EA et al (2017) Selection method and proposals to the use of geodiversity sites: the case of the north coast of São Paulo state, Brazil [Método de seleção e propostas de uso dos sítios da geodiversidade: Exemplo do litoral norte do estado de São Paulo, Brasil]. Anu do Inst Geociencias 40:24 47. https:// doi.org/10.11137/2017_3_24_47

Bíró KT (1984) Distribution of obsidian from the Carpathian Sources on Central European Palaeolithic and Mesolithic sites. Acta Archaeol Carpathica 23:5-42

Bíró KT (2002) Advances in the study of early Neolithic lithic materials in Hungary. Antaeus 25:119-168

Brilha J (2016) Inventory and Quantitative assessment of geosites and geodiversity sites: a review. Geoheritage 8:119-134. https://doi.org/ 10.1007/s12371-014-0139-3

Brilha J (2017) Geoheritage and geoparks. Geoheritage Assessment, Prot Manag:323-335. https://doi.org/10.1016/B978-0-12-809531-7. 00018-6

Browne MAE (2012) Geodiversity and the role of the planning system in Scotland. Scottish Geogr J 128:266-277. https://doi.org/10.1080/ 14702541.2012.725862

Carreras J, Druguet E (1999) Geological heritage, an essential part of the integral management of world heritage in protected sites. In: Barettino D, Wimbledon WAP, Gallego E (eds) Geological heritage: its conservation and management. Third International Symposium ProGEO on the Conservation of the Geological Heritage. Madrid, pp 95-110

Coratza P, Hobléa F (2018) The specificities of geomorphological heritage. Geoheritage:87-106. https://doi.org/10.1016/B978-0-12809531-7.00005-8

Coratza P, Gauci R, Schembri J, Soldati M, Tonelli C (2016) Bridging natural and cultural values of sites with outstanding scenery: evidence from Gozo, Maltese islands. Geoheritage 8:91-103. https:// doi.org/10.1007/s12371-015-0167-7

CORINE Land Cover 2006 seamless vector data (2016) http://www.eea. europa.eu/data-and-maps/data/clc-2006-vector-data-version accessed 26th February 2016

Czech Geological Survey (2014) Significant geological localities of the Czech Republic. http://www.geology.cz/\%0Aextranet-eng/ geology-for-all/geological-localities

de Lima FF, Brilha JB, Salamuni E (2010) Inventorying geological heritage in large territories: a methodological proposal applied to Brazil. Geoheritage 2:91-99. https://doi.org/10.1007/s12371-010-0014-9

Di Fazio S, Modica G (2018) Historic rural landscapes: sustainable planning strategies and action criteria. The Italian experience in the global and European context. Sustain 10:1-27. https://doi.org/10.3390/ su10113834
Erhardt G, Pentelényi L (1966) Geological map of the Tokaj Mts. 1: 25000. Tornyosnémeti. Hung. Geol Inst

Ésik Z, Szepesi J (2017) Az Abák vidékének ismeretlen szurdokvölgye. In: Nagy B (ed) Magyarország rejtőzködő túraútvonalai. IPC könyvek, pp 32-40

Ésik Z, Rózsa P, Szepesi J (2019) Geoheritage elements of millstone manufactory, Tokaj Mountains, Hungary. Eur Geoliogist 48:38-42

Esmark J (1798) Kurze Beschreibungen einer mineralogische Reise durch Ungarn, Siebenbürgen und das Bahnat. Freiberg

Faccini F, Gabellieri N, Paliaga G, Piana P, Angelini S, Coratza P (2018) Geoheritage map of the Portofino Natural Park. 5647. https://doi. org/10.1080/17445647.2018.1433561

Fichtel JE (1791) Mineralogische Bemerkungen von den Karpathen 2-

Frisnyák S (2009) A táj és a természeti erőforrások használata. In: Antropogén ökológiai változások a Kárpát-medencében. L'Harmattan, Pécs, pp 145-163

Fuertes-Gutiérrez I, Fernández-Martínez E (2010) Geosites inventory in the Leon Province (Northwestern Spain): a tool to introduce geoheritage into regional environmental management. Geoheritage 2:57-75. https://doi.org/10.1007/s12371-010-0012-y

Fuertes-Gutierrez I, Fernandez-Martinez E (2012) Mapping geosites for geoheritage management: a methodological proposal for the regional park of Picos de Europa (Leon, Spain). Environ Manage 50:789806. https://doi.org/10.1007/s00267-012-9915-5

Gatley S, Parkes M (2018) The selection of and characters of a geositeexamples from Ireland. 157-167

Geological Survey of Spain (2014) Spanish inventory of sites of geological int erest. http://info.igme.es/ielig/

Gordon JE (2018a) Geotourism and cultural heritage. In: Dowling R, Newsome D (eds) Handbook of geotourism. Edwar Elgar Publishing, Cheltenham, pp 61-75

Gordon JE (2018b) Geoheritage, geotourism and the cultural landscape: enhancing the visitor experience and promoting geoconservation. Geosci 8. https://doi.org/10.3390/geosciences 8040136

Gray M (2004) Geodiversity: valuing and conserving abiotic nature. John Wiley \& Sons Ltd

Gray M (2008) Geodiversity: developing the paradigm. Proc Geol Assoc 119:287-298. https://doi.org/10.1016/S0016-7878(08)80307-0

Guimarães GB, de Lima FF, Rocha-Campos AC (2018) Chapter 23Varvite Park, a Brazilian initiative for the conservation and interpretation of geoheritage. Geoheritage 405-415. https://doi.org/10. 1016/B978-0-12-809531-7.00023-X

Gyarmati P (1963) Geological map of the Tokaj Mts. 1:25000. Tolcsva. Hung. Geol Inst.

Gyarmati P (1966) Geological map of the Tokaj Mts. 1:25000. Háromhuta. Hung. Geol Inst.

Gyarmati P (1972) Geological map of the Tokaj Mts. 1:25000. Sárospatak. Hung. Geol Inst.

Gyarmati P, Pentelényi L (1973) Geological map of the Tokaj Mts. 1: 25000. Makkoshotyka-Sátoraljaújhely. Hung. Geol Inst.

Hartai É, Németh N (2012) The Telkibánya Field Training Educational Park in working order. In: Strba L (ed) Geoparks, geoheritage and geoconservation - IRSE: History of Central European Mining. Technical University of Kosice, Kosice, pp 6-15

Horváth G, Csüllög G (2013) A new slovakian-hungarian cross-border geopark in Central Europe -possibility for promoting better connections between the two countries. Eur Countrys 5:146-162. https:// doi.org/10.2478/euco-2013-0010

Horváth G, Lóczy D (2015) Geoheritage, geomorphosites in Hungary. In: Lóczy D (ed) Landscape and landforms of Hungary. Sprineger Switzerland, pp 281-288

ICOMOS Hungary (2017) Citrom és savanyú szőlő. Archeologia

Ilkey-Perlaki E (1967) Geological map of the Tokaj Mts. 1:25000. Fony. Hung. Geol Inst.

Ilkey-Perlaki E (1971) Geological map of the Tokaj Mts. 1:25000. Gönc. Hung. Geol Inst 
Ilkey-Perlaki E (1977) Geological map of the Tokaj Mts. 1:25000. Nyíri. Hungarian Geological Institute

International Council on Monuments and Sites (2008) ICOMOS International Cultural Tourism Charter: principles and guidelines for managing tourism at places of cultural and heritage significance. Tourism 1-9

Kiss G (2011) Mindennapi kisemlékeink megőrzéséért. Vidékf ejlesztési Minisztérium Környezet- és Természetvédelmi Helyett es Államt itkársága

Kiss G, A H, Orsolya B (1999) Komlóskai “telér" tanösvény Kirándulásvezető-füzet. Komlóska Község Önkormányzata

Kiss G, Szepesi J, Tamás O, et al (2002) „Kormos Bába” tanösvény. HOLOCÉN Természetvédelmi Egyesület, Miskolc

Kiss P, Gméling K, Molnár F, Pécskay Z (2011) Geochemistry of Sarmatian volcanic rocks in the Tokaj Mts (NE Hungary) and their relationship to hydrothermal mineralization. Cent Eur Geol 53:377403. https://doi.org/10.1556/CEuGeol.53.2010.4.3

Kováč M, Andreyeva-grigorovich A, Bajraktarević Z et al (2007) Badenian evolution of the Central Paratethys Sea: paleogeography, climate and eustatic sea-level changes. Geol Carpathica 58:579-606

Kubalíková L (2013) Geomorphosite assessment for geotourism purposes. Czech J Tour 2(2):80-104. https://doi.org/10.2478/cjot2013-0005.Abstract

Kubalíková L (2019) Assessing geotourism resources on a local level : a case study from Southern Moravia (Czech Republic ). 10.3390/ resources 8030150

Lakner Z, Kiss A, Merlet I, Oláh J, Máté D, Grabara J, Popp J (2018) Building coalitions for a diversified and sustainable tourism: two case studies from Hungary. Sustain 10:1-23. https://doi.org/10. 3390/su10041090

Li Q, Wumaier K, Ishikawa M (2019) The spatial analysis and sustainability of rural cultural landscapes: Linpan settlements in China's Chengdu Plain. Sustainability 11:4431. https://doi.org/10.3390/ su11164431

Lóczy D (2002) Tájértékelés, földértékelés. Dialóg Campus

Marosi S (1985) Tájkutatási irányzatok, tájértékelés, tájtipológiai eredmények, Elmélet-Mó. MTA FKI, Budapest

Mata-Perelló J, Carrión P, Molina J, Villas-Boas R (2017) Geomining heritage as a tool to promote the social development of rural communities. Geoheritage Assessment, Prot Manag:167-177. https:// doi.org/10.1016/B978-0-12-809531-7.00009-5

Mauerhofer L, Reynard E (2018) Contribution of a geomorphosite inventory to the geoheritage knowledge in developing countries : the case of the Simien Mountains National Park, Ethiopia. 559-574. https:// doi.org/10.1007/s12371-017-0234-3

Migoń P, Latocha A (2013) Human interactions with the sandstone landscape of central Sudetes. Appl Geogr 42:206-216. https://doi.org/ 10.1016/j.apgeog.2013.03.015

Migoń P, Pijet-Migoń E (2016) Overlooked geomorphological component of volcanic geoheritage - diversity and perspectives for tourism industry, Pogórze Kaczawskie Region, SW Poland. Geoheritage 8: 333-350. https://doi.org/10.1007/s12371-015-0166-8

Migoń P, Pijet-Migoń E (2017) Viewpoint geosites - values, conservation and management issues. Proc Geol Assoc 128:511-522. https:// doi.org/10.1016/j.pgeola.2017.05.007

Mitchell N, Rössler M, Tricaud P-M (2009) World heritage cultural landscapes: a handbook for conservation and management

MSZ 20381:2009 (2009) Természetvédelem. Egyedi tájértékek kataszterezése. 17

Novák TJ, Szepesi J (2018) Soils of the abandoned gold and silver mining area on volcanic-hydrothermal rocks (Hungary). In: Soil Sequences Atlas III. Nicolaus Copernicus University, Torun, pp 137-149

Pécskay Z, Lexa J, Szakács A et al (2006) Geochronology of Neogene magmatism in the Carpathian arc and intra-Carpathian area. Geol Carpathica 57:511-530
Pentelényi L (1970) Geological map of the Tokaj Mts. 1:25000. Abaújszántó. Hung. Geol Inst.

Pentelényi L (1971) Geological map of the Tokaj Mts. 1:25000. Erdőbénye. Hung. Geol Inst.

Pentelényi L (1972) Geological map of the Tokaj Mts. 1: 25000.Füzérradvány-Széphalom. Hung. Geol Inst.

Pereira P, Pereira D (2010) Methodological guidelines for geomorphosite assessment. Géomorphologie Reli Process Environ 16:215-222

Piller WE, Harzhauser M, Mandic O (2007) Miocene Central Paratethys stratigraphy - current status and future directions. Stratigraphy 4 : $151-168$

Pinczés Z (1998) A Tokaji-hegység geomorfológiai nagyformái. Foldr Ert 3:379-393

Poiraud A, Chevalier M, Claeyssen B, Biron PE, Joly B (2016) From geoheritage inventory to territorial planning tool in the Vercors massif (French Alps): contribution of statistical and expert cross approaches. Appl Geogr 71:69-82. https://doi.org/10.1016/j.apgeog. 2016.04.012

Prosser CD (2018) Geoconservation, quarrying and mining: opportunities and challenges illustrated through working in partnership with the mineral extraction industry in England. Geoheritage 10:259-270. https://doi.org/10.1007/s12371-016-0206-z

Prosser CD, Díaz-Martínez E, Larwood JG (2017) The conservation of geosites: principles and practice. Geoheritage Assessment, Prot Manag 193-212. https://doi.org/10.1016/B978-0-12-809531-7. 00011-3

Regolini-Bissig G, Reynard E (2010) Mapping geoheritage_6 papers. Inst Geogr Geovisions:127

Reynard E (2009) Geomorphosites: definitions and characteristics. In: Reynard E, Coratza P, Regolini-Bissig G (eds) Geomorphosites. Pfeil, München, pp 9-20

Reynard E, Giusti C (2017) The landscape and the cultural value of geoheritage. Elsevier Inc.

Reynard E, Giusti C (2018) The landscape and the cultural value of geoheritage. Elsevier Inc.

Reynard E, Fontana G, Kozlik L, Scapozza C (2007) A method for assessing "scientific" and "additional values" of geomorphosites. Geogr Helv 62:148-158. https://doi.org/10.5194/gh-62-148-2007

Richthofen F (1861) Studie aus dem ungarisch-siebenbürgischen Trachytgebirgen. Jahrb d k.k Geol Reichsanst 11:153-278

Rolfo F, Benna P, Cadoppi P, Castelli D, Favero-Longo SE, Giardino M, Balestro G, Belluso E, Borghi A, Cámara F, Compagnoni R, Ferrando S, Festa A, Forno MG, Giacometti F, Gianotti F, Groppo C, Lombardo B, Mosca P, Perrone G, Piervittori R, Rebay G, Rossetti P (2015) The Monviso Massif and the Cottian Alps as symbols of the alpine chain and geological heritage in Piemonte, Italy. Geoheritage 7:65-84. https://doi.org/10.1007/s12371-0140097-9

Ruban DA (2019) Jurassic trace fossil localities of adygeya (Russia): new geoheritage under anthropogenic pressure. J Geogr Inst Jovan Cvijic SASA 69:83-89. https://doi.org/10.2298/IJGI1901083R

Sharples C (1993) A methodology for the identification of significant landforms and geological sites for geoconservation purposes. Forestry Commission of Tasmania

Sharples C (2002) Concepts and principles of geoconservation. Tasmanian Park Wildl Serv website 2002:81

SRTM global DEM https://ta.cr.usgs.gov/SRTM1Arc)

Szakáll S, Gatter I (1993) Magyarországi ásványfajok. Fair System Kft., Budapest

Szepesi J, Sütő L, Soós I (2015) Vizsoly, riolittufa kőfejtő földtani alapszelvény - természeti emlék természetvédelmi kezelési tervdokumentációja

Szepesi J, Harangi S, Ésik Z, Novák TJ, Lukács R, Soós I (2017) Volcanic geoheritage and geotourism perspectives in Hungary: a case of an UNESCO World Heritage Site, Tokaj Wine Region 
Historic Cultural Landscape, Hungary. Geoheritage 9:329-349. https://doi.org/10.1007/s12371-016-0205-0

Szepesi J, Ésik Z, Soós I, et al (2018a) Földtani objektumok értékminősítése: módszertani értékelés a védelem, bemutatás, fenntarthatóság és a geoturisztikai fejlesztések tükrében. Földtani Közlöny 148:143-160. 10.23928/foldt.kozl.2018.148.2.143

Szepesi J, Lukács R, Bíró K.T, et al (2018b) Geology of Tokaj Mountains obsidians. Archeometriai Mühely XV:167-179

Szepesi J, Lukács R, Soós I, Benkó Z, Pécskay Z, Ésik Z, Kozák M, di Capua A, Groppelli G, Norini G, Sulpizio R, Harangi S (2019) Telkibánya lava domes: Lithofacies architecture of a Miocene rhyolite field (Tokaj Mountains, Carpathian-Pannonian region, Hungary). J Volcanol Geotherm Res. 385:179-197. https://doi.org/ 10.1016/j.jvolgeores.2019.07.002

Timothy J, Witt JD (2019) Legal aspects of rock, mineral, and fossil collecting. https://geology.com/minerals/legal-aspects-of-rockcollecting/

Tóth S, Szijártó Á, Kiss G (2012) Az egyedi tájértékek nyilvántartásának tájvédelmi szempontú elemzése. J Landsc Ecol 10:139-152

UNESCO (2014) United Nations Educational, Scientific and Cultural Organization Organisation des Nations Unies pour l'éducation, la science et la culture Guidelines and Criteria for National Geoparks seeking UNESCO's assistance to join the Global Geoparks Network (GGN). 13
Vujičić MD, Vasiljević DA, Marković SB, Hose TA, Lukić T, Hadžić O, Janićević S (2011) Preliminary geosite assessment model (GAM) and its application on fruška gora mountain, potential geotourism destination of Serbia. Acta Geogr Slov 51:361-377. https://doi.org/ 10.3986/AGS51303

Wimbledon WAP (1999) GEOSITES - an International Union of Geological Sciences initiative to conserve our geological heritage. 8:5-8

Zangmo GT, Kagou AD, Nkouathio DG, et al (2017) The volcanic geoheritage of the Mount Bamenda Calderas (Cameroon Line): assessment for geotouristic and geoeducational purposeS. 255-278. 10.1007/s12371-016-0177-0

Zangmo GT, Román AQ, Umaña DP (2020) Geomorphosites inventory in the Eboga Volcano (Cameroon): contribution for geotourism promotionInventaire des géomorphosites du volcan Eboga (Cameroun): contribution à la promotion du géo-tourisme. Géomorphologie Reli Process Environ 26

Zelenka T, Gyarmati P, Kiss J (2012) Paleovolcanic reconstruction in the Tokaj Mountains. Cent Eur Geol 55:49-83. https://doi.org/10.1556/ CEuGeol.55.2012.1.4

Zouros N (2005) Assessment, protection, and promotion of geomorphological and geological sites in the Aegean area, Greece. Géomorphologie Reli Process environnement, 2005:227-234. https://doi.org/10.1017/CBO9781107415324.004, www.geomania. hu, accessed 21.01.2020 